\title{
Solar Photooxygenations for the Manufacturing of Fine Chemicals-Technologies and Applications
}

\author{
Jayson S. Wau ${ }^{1}$, Mark J. Robertson ${ }^{1}$ (D) and Michael Oelgemöller ${ }^{1,2, *(D)}$ \\ 1 College of Science and Engineering, James Cook University, Townsville, QLD 4811, Australia; \\ jayson.wau@my.jcu.edu.au (J.S.W.); mark.robertson@jcu.edu.au (M.J.R.) \\ 2 Department of Organic and Macromolecular Chemistry, Ghent University, Krijgslaan 281 S4, \\ 9000 Gent, Belgium \\ * Correspondence: michael.oelgemoeller@jcu.edu.au; Tel.: +61-7-4781-4543
}

Citation: Wau, J.S.; Robertson, M.J.;

Oelgemöller, M. Solar

Photooxygenations for the

Manufacturing of Fine

Chemicals-Technologies and

Applications. Molecules 2021, 26,

1685. https://doi.org/10.3390/

molecules26061685

Academic Editor: Axel G. Griesbeck

Received: 18 February 2021

Accepted: 15 March 2021

Published: 17 March 2021

Publisher's Note: MDPI stays neutral with regard to jurisdictional claims in published maps and institutional affiliations.

Copyright: (c) 2021 by the authors. Licensee MDPI, Basel, Switzerland. This article is an open access article distributed under the terms and conditions of the Creative Commons Attribution (CC BY) license (https:// creativecommons.org/licenses/by/ $4.0 /)$.

\begin{abstract}
Photooxygenation reactions involving singlet oxygen $\left({ }^{1} \mathrm{O}_{2}\right)$ are utilized industrially as a mild and sustainable access to oxygenated products. Due to the usage of organic dyes as photosensitizers, these transformations can be successfully conducted using natural sunlight. Modern solar chemical reactors enable outdoor operations on the demonstration (multigram) to technical (multikilogram) scales and have subsequently been employed for the manufacturing of fine chemicals such as fragrances or biologically active compounds. This review will highlight examples of solar photooxygenations for the manufacturing of industrially relevant target compounds and will discuss current challenges and opportunities of this sustainable methodology.
\end{abstract}

Keywords: solar chemistry; photooxygenations; solar reactor; chemical manufacturing

\section{Introduction}

Photochemistry has recently seen a remarkable renaissance in synthetic organic chemistry [1-4]. This trend was sparked by the development of new photochemical transformations [5-8] as well as advances in photoreactor and light technologies [9-13]. However, the large-scale realization of photochemical manufacturing processes is hindered by their quantum yields and the significant installation and maintenance costs of artificial light sources $[14,15]$. As a result, industrial photochemistry is restricted to low-volume but high-value fine chemicals (such as fragrances, flavors or vitamins), or bulk but low-value chemicals (such as haloalkanes, oximes, sulfonyl chlorides and sulfonic acids) [14-19]. Natural sunlight is regarded as an alternative and sustainable energy source for a range of photochemical transformations [20-23]. Up until the early 20th century, photochemical experiments were routinely performed by placing sealed flasks and tubes in direct sunlight [24-27]. Although this 'flask in the sun' approach is still followed today [28,29], the small scales and prolonged exposure times result in very low productivities of the desired products. Recently, sunlight collectors and concentrators that were initially developed for energy generation [30-33] have been modified for solar photochemical experimentation [34]. Technical-scale solar degradation and detoxification processes have subsequently been successfully realized using these technologies [35-38]. In contrast, however, preparative solar chemistry for the manufacturing of chemicals is still comparably rare [39-47]. The main hurdles for a widespread implementation of solar synthesis are the discontinuous availability and the low UV content $(<400 \mathrm{~nm})$ of just $3-5 \%$ of natural sunlight [48]. Sunlight also consists largely of direct and diffuse radiation and their ratios vary with the location and weather [49]. Solar manufacturing may thus be ideally performed in the visible range (400-700 nm: 42-43\% of solar spectrum [48]) for small annual production targets ( $<100$ tons/year) that do not require continuous, year-round operation under optimal solar light conditions. Photooxygenations with singlet oxygen $\left({ }^{1} \mathrm{O}_{2}\right)$ combine catalytic 


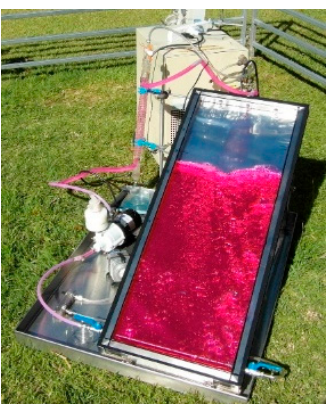

(a)

amounts of a dye sensitizer with visible light and yield a variety of oxygenated products [50-52]. Photooxygenations are also performed industrially to produce low-volume fine chemicals such as fragrances, flavors or pharmaceuticals [53-55]. These features make photooxygenations ideal candidates for solar chemical manufacturing processes.

\section{Solar Reactors for Synthetic Applications}

Solar reactors are classified based on their sun concentration factor (CF) and range from non- to highly concentrating systems. Non- and low concentrating reactors are characterized by large apertures that enable them to harvest direct and diffuse radiation. The simplest non-concentrating devices are flatbed reactors with large surface areas, thin bodies, and operation volumes of up to $30 \mathrm{~L}$ (Figure 1a) [56]. These fixed reactors are best tilted to the latitude of the location for optimal harvest of sunlight. Improved models operate in circulation mode with an external heat exchanger. The compound parabolic collector (CPC) uses a 'round W'-shaped polished aluminum reflector that is tilted to the local latitude and directs all available radiation onto a central received tube (Figure 1b) $[57,58]$. These advanced systems have a concentration factor of one sun (or slightly above) and most commonly operate in circulating batch mode on volumes of up to $100 \mathrm{~L}$. Several reactors can also be connected in series to form larger units. Parabolic trough reactors utilize large reflectors that focus only direct sunlight onto a reaction tube in their focal line and can reach concentration factors of 20-150 suns [32]. More modern reactors such as the former PROPHIS loop (PaRabolic trough-facility for Organic PHotochemical synthesis, Figure 1c) operate on volumes up to $150 \mathrm{~L}$ and track the movement of the sun, either horizontally or three-dimensionally (horizontally and vertically) [59].

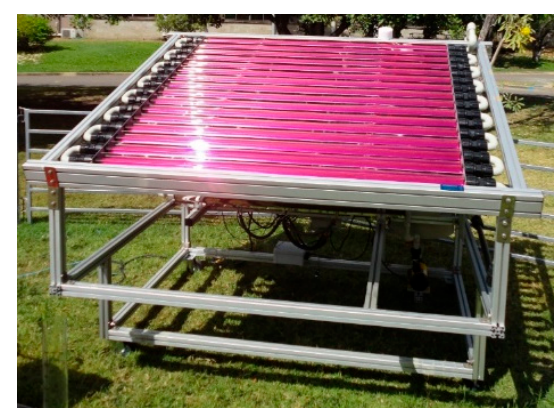

(b)

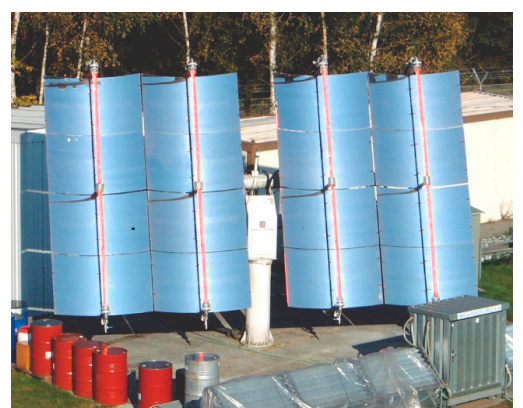

(c)

Figure 1. (a) Circulating flatbed reactor with reflective back and external cooling at James Cook University in Townsville, Australia. (b) CPC reactor with a $2 \mathrm{~m}^{2}$ aperture at James Cook University in Townsville, Australia. (c) Former PROPHIS loop at the German Aerospace Center (DLR) in Cologne-Porz, Germany (modified from [60]).

While solar dish concentrators can provide very high concentration factors of up to 5000 suns, these sophisticated devices are rarely used for preparative solar photochemical applications. Since the receiver in the focal point easily reaches extreme temperature ranges, dish reactors are instead advantageous for thermochemical processes [33]. Likewise, solar furnaces can reach extreme concentration factors of 5000-20,000 suns by reflecting sunlight via a heliostat or heliostat field onto a concentrator, which then focuses the sun's beam onto the experimental setup. The naturally extreme heat generation and the costly installation have limited the application of solar furnaces mainly to material sciences and solar thermal research activities [61-63].

\section{Photooxygenations in Organic Synthesis}

Photooxygenations, also known as Type II photosensitized oxidations [64], utilize singlet oxygen $\left({ }^{1} \mathrm{O}_{2}\right)$, which is generated from ground-state triplet oxygen $\left({ }^{3} \mathrm{O}_{2}\right)$ via photosensitization (Scheme 1) [65]. The sensitizer (Sens) initially absorbs light and undergoes intersystem crossing (ISC) to its triplet excited state $\left({ }^{3}\right.$ Sens $\left.{ }^{*}\right)$. Subsequent energy transfer 
to ground state oxygen produces singlet oxygen. The dissolved oxygen concentration in most organic solvents is low $[66,67]$ and thus, fine streams of oxygen or compressed air are constantly passed through the reaction media. Likewise, the lifetime of singlet oxygen critically depends on the reaction medium and is highest in halogenated solvents [67]. Due to the environmental hazards linked to these solvents, many industrial and solar photooxygenation processes are conducted in less harmful alcoholic solvents instead [68]. A series of photosensitizers with large absorption coefficients within the visible spectrum, suitable solubilities in a range of organic solvents, long triplet lifetimes and high quantum yields for ${ }^{1} \mathrm{O}_{2}$ generation have now become available $[69,70]$. The most common photosensitizers methylene blue, tetraphenylporphyrin and rose bengal (as disodium salt) are shown in Scheme 1. For easy recovery and reuse, photosensitizers have also been immobilized on an inert solid support [71,72]. Photooxygenations have furthermore been successfully performed under continuous-flow conditions [73]. Thermal oxygenation processes involving ${ }^{1} \mathrm{O}_{2}$ have likewise been developed but are at present less important in organic synthesis [74].

$$
\text { Sens } \stackrel{\mathrm{h} v}{\longrightarrow}{ }^{1} \text { Sens }^{*} \stackrel{\mathrm{ISC}}{\longrightarrow}{ }^{3} \text { Sens }^{*} \stackrel{{ }^{3} \mathrm{O}_{2}}{\underbrace{\longrightarrow}_{\text {Sens }}}{ }^{1} \mathrm{O}_{2}
$$

Methylene blue (MB)<smiles>CN(C)c1ccc2cc3ccc(=[N+](C)C)cc-3sc2c1</smiles><smiles>NC(=O)c1c(Cl)c(Cl)c(Cl)c(C(N)=O)c1-c1c2cc(I)c(=O)c(I)c-2oc2c(I)c(O[Na])c(I)cc12</smiles>

Scheme 1. Photosensitized generation of singlet oxygen and common photosensitizers.

Singlet oxygen can react with a variety of functional groups (Scheme 2) [50-52]. Conjugated dienes preferably undergo [4+2] cycloadditions to endoperoxides, while electron-rich olefins favor [2+2] cycloadditions to 1,2-dioxetanes. Inactivated olefins with allylic hydrogen atoms undergo Schenck-ene-type reactions to allylic hydroperoxides instead [75,76]. Thioethers and phosphines produce the corresponding sulfoxides and phosphine oxides. All reaction types incorporate molecular oxygen into a molecular entity with high to quantitative atom economies.

[4+2] Cycloaddition<smiles>C=C/C=C\C</smiles><smiles>O=[N+]([O-])[O-]</smiles>

endoperoxides

\section{[2+2] Cycloaddition}

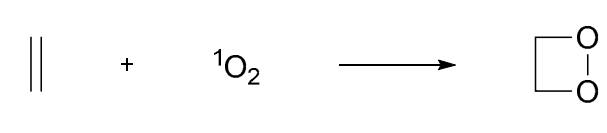

dioxetanes
Schenck-ene-Reaction<smiles>C=CCOOO</smiles>

hydroperoxides
S/P-Oxidation

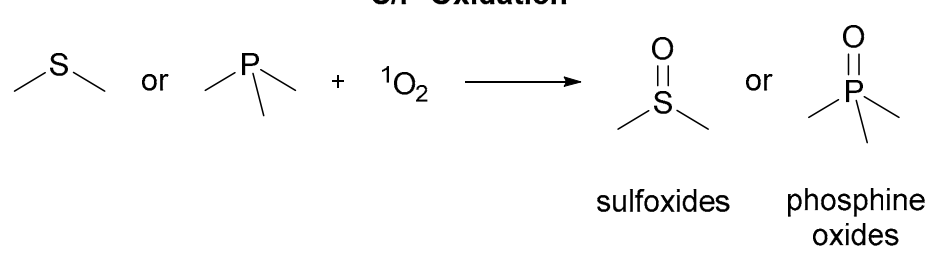

Scheme 2. General photooxygenation reactions. 
Many of the industrially relevant photochemical processes convert naturally occurring or semi-synthetic starting materials to their corresponding oxygenated products [53-55]. Of these, essential oil derived starting materials are especially common $[55,77]$, which makes photooxygenations promising applications for product diversification and value-adding in the essential oil industry [78]. This review will focus on demonstration (multigram)to technical (multikilogram)-scale transformations conducted in purpose-designed solar reactors. Whenever available, key technical features of the solar reactor systems used have been provided. Related demonstration-scale photooxidations involving the super oxide anion radical $\left(\mathrm{O}_{2}{ }^{\bullet-}\right)$ or a thermal oxidation step were also included. In many cases, solar transformations were monitored, and obtained product mixtures analyzed by GC or GC-MS analysis techniques. Whenever necessary, the reported yields or conversions from these studies were rounded for consistency and to account for experimental errors.

\section{Solar Preparative Photooxygenations}

\subsection{Photooxygenation of $\alpha$-Terpinene and Related Reactions}

The first improvised solar manufacturing plant was built after the Second World War in Germany by the late Prof. Günther Otto Schenck (Figure 2). The plant produced ascaridole (2) (Scheme 3), which was urgently needed at that time to fight ascaris infections in humans [79-81]. The plant consisted of 200 carboy glass bottles of $10 \mathrm{~L}$ each that were placed in rows on wooden racks. Each flask was filled with $5 \mathrm{~L}$ of air-saturated ethanol solutions of $\alpha$-terpinene (1) [54]. Stinging nettles (or spinach) leaves served as chlorophyll and hence photosensitizer source. During solar exposure, the flasks were sprayed from above with water for cooling and shaken regularly for mixing and to maintain oxygen saturation. In just two sunny summer days, the entire plant was able to produce ca. $2 \mathrm{~kg}$ of ascaridole (2). The application of ascaridole as an anthelmintic drug was later discouraged due to its severe side effects and its solar production was subsequently discontinued. Despite this, the photooxygenation of $\alpha$-terpinene (1) still serves as a common model reaction in the development of new photosensitizers or photochemical reactor systems.

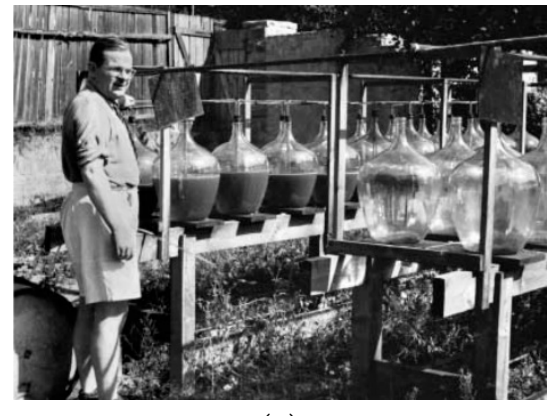

(a)

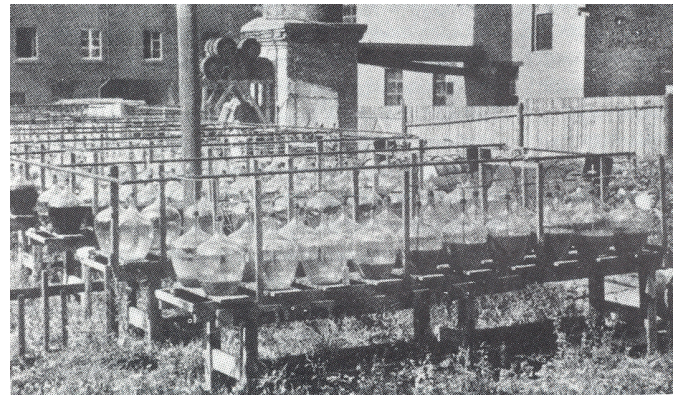

(b)

Figure 2. Solar production plant for the synthesis of ascaridole (2). (a) Prof. Günther Otto Schenck in front of a row of reaction bottles (taken from [47]). (b) The entire plant in Ziegelhausen, Germany, around 1949 (taken from [54]).<smiles>CC1=CC=C(C(C)C)CC1</smiles>

1

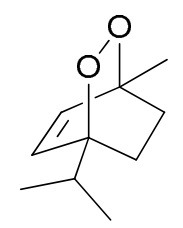

2
$40 \mathrm{~g}$ of 1 in $5 \mathrm{~L}$ air-saturated $\mathrm{EtOH}$ 100-200 $\mathrm{g}$ of stinging nettle leaves (chlorophyll) ca. $10 \mathrm{~g}$ (ca. $20 \%$ ) of 2 in 2 sunny days (summer) ca. $2 \mathrm{~kg}$ of 2 for the whole plant (200 bottles)

Scheme 3. General photooxygenation reactions. 
The photooxidation of $\alpha$-terpinene (1) in the presence of a benzocoumarin sensitizer (3) and in concentrated sunlight has been reported by Karapire and co-workers (Scheme 4) [82]. The authors used a small Fix Focus dish reactor with a cylindrical water-cooled Pyrex photoreactor vessel in its focal point (Figure 3). The dish concentrator had a focal length of $0.65 \mathrm{~m}$, a usable reflective surface area of $2.66 \mathrm{~m}^{2}$ (total of $3.68 \mathrm{~m}^{2}$ ) and a reflective aluminized polymer film cover $\left(40 \mu \mathrm{m}\right.$ thick layer with $0.91 \mathrm{~g} / \mathrm{cm}^{3}$ of alumina). The device tracked the sun only for the elevation and required manual focusing for its azimuth. The concentration factor at the reactor's focal point could be adjusted between 40 and 150 suns depending on experimental requirements. Solutions of $\mathbf{1}(0.1 \mathrm{M})$ and catalytic amounts of 3 in acetonitrile were exposed to concentrated sunlight (at 130-150 suns) for $15 \mathrm{~min}$ and $4 \mathrm{~h}$ while air was passed through the reaction mixtures. Portions of the solutions were subsequently treated with sodium sulfite $\left(\mathrm{Na}_{2} \mathrm{SO}_{3}\right)$ and analyzed by GC-MS Photoproducts were assigned based on their MS-spectra and characteristic molecular ions but were not isolated. Short illumination for $15 \mathrm{~min}$ resulted in an incomplete conversion of 1 of approx. $83 \%$ and furnished $p$-cymene (4) as the main product in ca. $49 \%$. In addition, ascaridole (2), and the ring-opened compounds 5 and $\mathbf{6}$ were identified by GC-MS in smaller amounts of approx. $8 \%, 6 \%$ and $1 \%$, respectively. In contrast, prolonged exposure to concentrated sunlight for $4 \mathrm{~h}$ gave complete conversion of $\mathbf{1}$ and produced $p$-cymene (4) and ascaridole (2) as the main products in amounts of ca. $40 \%$ and $27 \%$. The ring-opened products 5, 6 and 7 were additionally formed with approx. $7 \%, 3 \%$ and $2 \%$, respectively. When the solar illumination for $4 \mathrm{~h}$ was repeated with nitrogen purging, no products were obtained. Based on these findings, the authors suggested that photooxidations involved both singlet oxygen $\left({ }^{1} \mathrm{O}_{2}\right)$ as well as super oxide anion radical $\left(\mathrm{O}_{2}{ }^{\bullet-}\right)$ pathways.

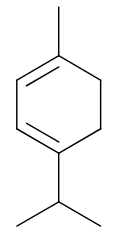

1
1. sunlight, cat. 3 , air, $\mathrm{MeCN}$

2. $\mathrm{Na}_{2} \mathrm{SO}_{3}$

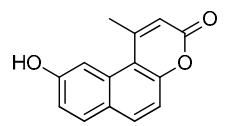

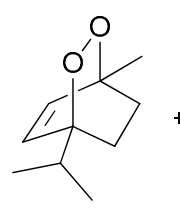

2

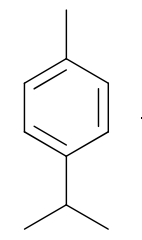

4

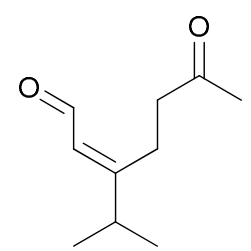

5

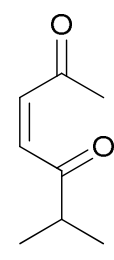

6<smiles>CC(C=O)=CCCC(=O)C(C)C</smiles>

7

$0.1 \mathrm{M}$ of 1 and 'few' $\mathrm{mg}$ of 3 in MeCN (50-125 mL)

ca. $83 \%$ conversion of 1 and $2: 4: 5: 6$ in ca. $8: 49: 6: 1 \%$ (by GC/MS) after 15 min at $130-150$ suns complete conversion of 1 and $2: 4: 5: 6: 7$ in ca. $27: 40: 7: 3: 2 \%$ (by GC/MS) after 4 hours at $130-150$ suns

Scheme 4. Photooxidation of $\alpha$-terpinene (1) with benzocoumarin sensitizer 3.

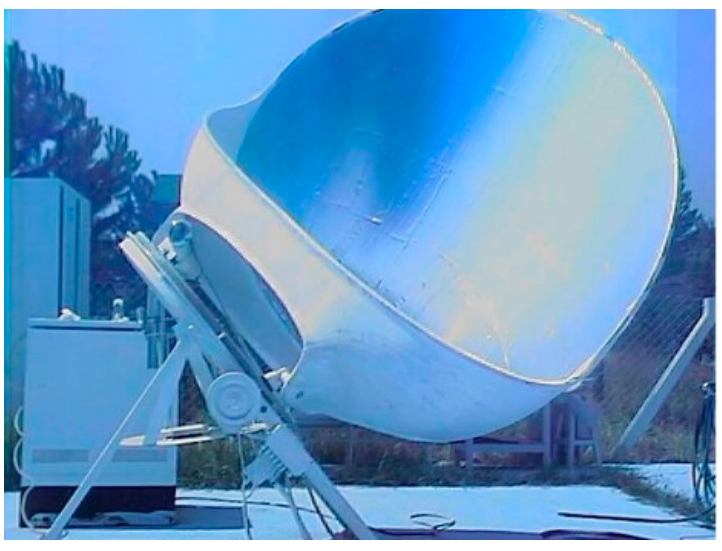

Figure 3. Parabolic dish solar concentrator (HTC Solar Research GmbH, Germany) at Ege University in Izmir, Turkey, around 2001 (taken from [83]). 
In an extension of this work, the same authors utilized perylenediimides as sensitizers in solution or immobilized in PVC or as sol-gel thin films on glass slides for the photooxidation of $\alpha$-terpinene (1) (Scheme 5) [84]. Illumination experiments were conducted for $15 \mathrm{~min}$ and $1 \mathrm{~h}$ in the same small parabolic dish reactor using concentration factors of 80-90 suns (Figure 3). After treatment of the reaction mixture with $\mathrm{Na}_{2} \mathrm{SO}_{3}$, the products obtained were detected and assigned by GC-MS analysis. The outcome of the reactions critically depended on the photosensitizer material and solar exposure conditions. In acetonitrile solution ( $0.1 \mathrm{M}$ of $\mathbf{1})$ with trace amounts of ABIPER photosensitizer (8a), solar exposure for $1 \mathrm{~h}$ gave ascaridole (2) as the dominant photoproduct in $96 \%$. Under the same conditions, the reaction with the 8a-containing sol-gel thin film remained incomplete with $20 \%$ of residual 1, and furnished ascaridole (2) and p-cymene (4) in amounts of ca. $49 \%$ and $18 \%$ as the main products. In contrast, the respective illumination with the PVC-immobilized sensitizer 8a predominantly formed 3,6-dioxoheptanal (9) in 55\%, next to $21 \%$ of ascaridole (2), $9 \%$ of $p$-cymene (4) and $16 \%$ of terpinolene (10), respectively. With soluble and sol-gel immobilized 8a, shorter illuminations in concentrated sunlight for just 15 min resulted in more complex product mixtures. When $N$-DODEPER $(\mathbf{8 b})$ was used as photosensitizer in acetonitrile solution, solar exposure for $1 \mathrm{~h}$ resulted in approx. $70 \%$ conversion and yielded predominantly $p$-cymene (4) and 3-isopropyl-2-heptanal-6-one (5) with ca. 51\% and $10 \%$, respectively. After the same illumination time, the corresponding $8 \mathbf{b}$ sol-gel thin film produced a conversion of $80 \%$ and furnished $p$-cymene (4) and ascaridole (2) as major products in ca. $34 \%$ and $15 \%$, as determined by GC-MS. The corresponding solar reaction with $8 \mathbf{b}$-impregnated PVC generated ca. $42 \%$ of 3,6-dioxoheptanal (9), 30\% of $p$-cymene (4), $11 \%$ of terpinolene (10) and $9 \%$ of ascaridole (2) as the main photoproducts instead. Shorter illuminations for $15 \mathrm{~min}$ again delivered different product mixtures and compositions. In the absence of any photosensitizer, GC-MS analysis after solar exposure for $1 \mathrm{~h}$ revealed an incomplete conversion of $\mathbf{1}$ of $57 \%$ with $p$-cymene (4), 3,6-dioxoheptanal (9), ascaridole (2), terpinolene (10) and cineol (11) as products in ca. 17\%, 16\%, 10\%, $9 \%$ and $6 \%$. In contrast, exposure to concentrated sunlight for just $15 \mathrm{~min}$ gave a very incomplete reaction $(<7 \%$ conversion) with cineole (11) as the only product in approx. 7\%. The formation of terpinolene (10) was suggested to occur via thermal rearrangement of $\mathbf{1}$. For all other products, the authors proposed reaction pathways via the super oxide anion radical $\left(\mathrm{O}_{2}{ }^{\bullet-}\right)$. The variable product compositions and the small scales $(25 \mathrm{~mL})$ prevent any wider exploitation of this synthesis methodology.

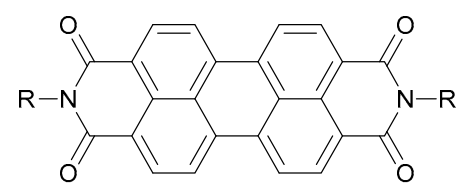

8

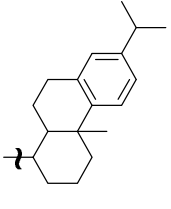

a (ABIPER)

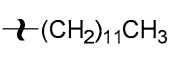

b $(N$-DODEPER)

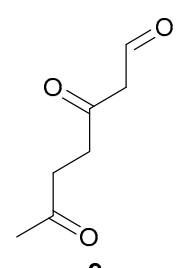

9

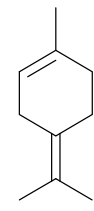

10

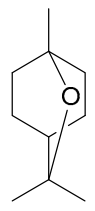

11

Scheme 5. Perylenediimide sensitizers $\mathbf{8} \mathbf{a}$ and $\mathbf{b}$ used and additional photoproducts $\mathbf{9 - 1 1}$ obtained during solar photooxidations of $\alpha$-terpinene.

The photodehydrogenation of $\alpha$-terpinene (1) to $p$-cymene (4) in concentrated sunlight has likewise been reported by Avcibasi and co-workers [85]. The authors reused the small Fix Focus dish reactor shown in Figure 3 but with a concentration factor of 40 suns. An initially degassed solution of $\mathbf{1}$, benzophenone $\left(\mathrm{Ph}_{2} \mathrm{CO}\right)$ and cupric pivalate $\left(\mathrm{CuPiv}_{2} ;\left({ }^{t} \mathrm{BuCO}_{2}\right)_{2} \mathrm{Cu}\right)$ in carbon tetrachloride was exposed to concentrated sunlight over a period of $4 \mathrm{~h}$ (Scheme 6). During this exposure, the reaction was stopped eight times for aeration/degassing that oxidized cuprous $\left(\mathrm{Cu}^{+}\right)$back to cupric $\left(\mathrm{Cu}^{2+}\right)$ ions. The reaction mixture was subsequently analyzed by GC-MS, which revealed a conversion of approx. $73 \%$ with ca. $47 \%$ of $p$-cymene (4). The postulated reaction mechanism involved hydrogen abstraction from $\alpha$-terpinene (1) by triplet-excited benzophenone followed by reduction of the resulting radical intermediate by $\mathrm{Cu}^{2+}$. 


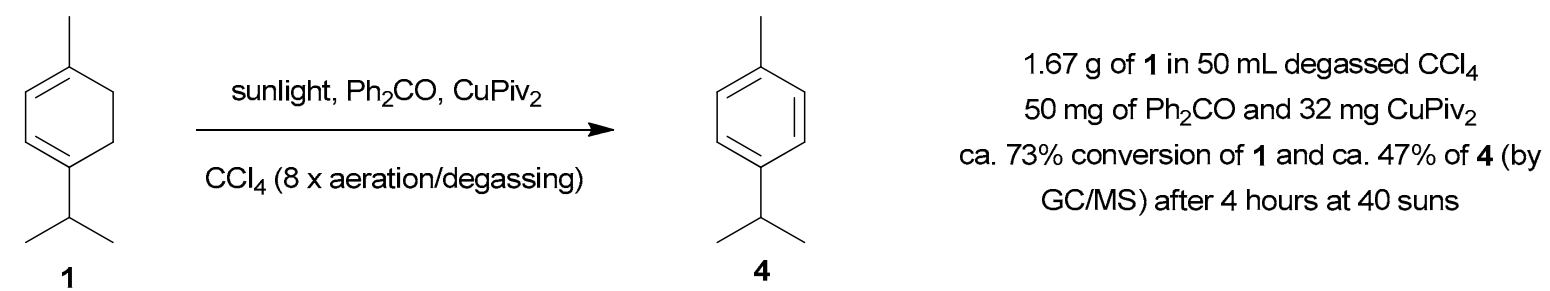

Scheme 6. Photodehydrogenation of $\alpha$-terpinene (1) to $p$-cymene (4).

\subsection{Photooxygenation of Citronellol for the Production of Rose Oxide}

The Schenck ene-photooxygenation of enantiomerically pure or racemic citronellol (12) is a key step in the synthesis of rose oxide (15), which serves as an important fragrance material in perfumery (Scheme 7) [86]. The initially obtained regioisomeric hydroperoxides 13a and $\mathbf{b}$ are reduced to their corresponding alcohols $\mathbf{1 4} \mathbf{a}$ and $\mathbf{b}$ in reported isolated yields of $60 \%$ and $35 \%$, respectively. Subsequent acid-catalyzed rearrangement and cyclization of 14a gives rose oxide (15) as a mixture of cis- and trans-diastereoisomers. Industrially, the photooxygenation of $\mathbf{1 2}$ is typically performed in methanol using rose bengal (RB) as a photosensitizer. After the additional thermal steps, rose oxide $\mathbf{1 5}$ is isolated from the crude reaction mixture by steam distillation in an overall yield of 50-60\%. The annual industrial production of rose oxide has been estimated to $>100$ tons [87]. A modified two-phase liquid/liquid cyclization process that utilizes both regioisomers $14 \mathbf{a}$ and $\mathbf{b}$ has also been patented [88].

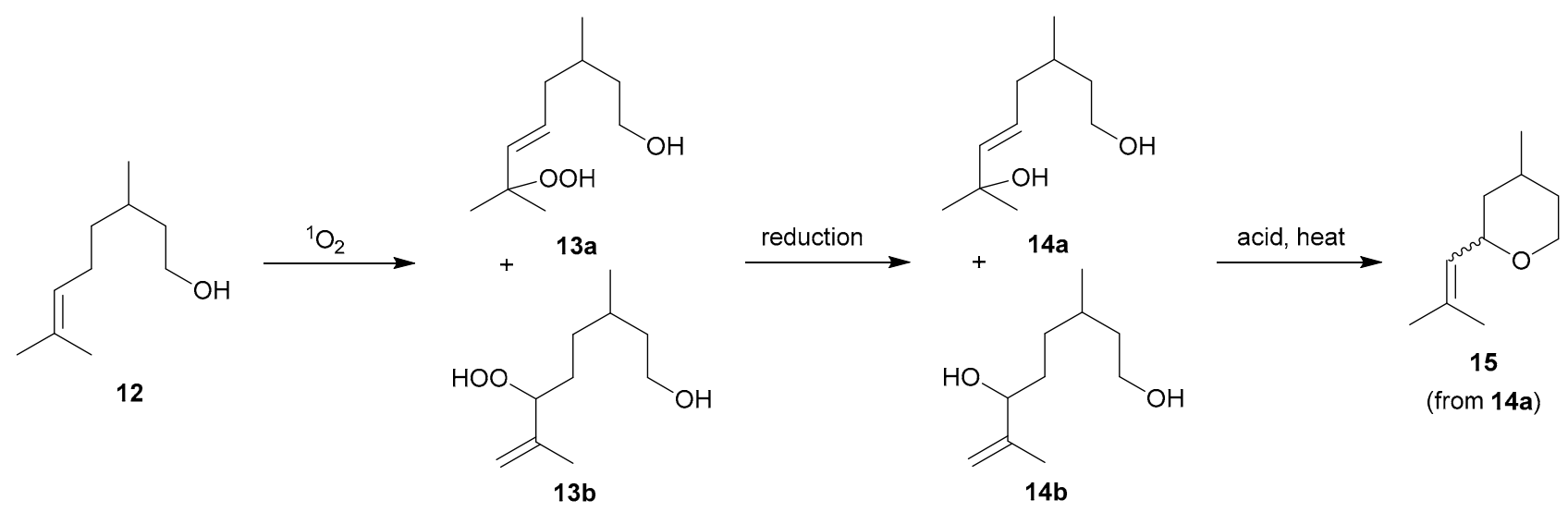

Scheme 7. Photooxygenation of citronellol (12) and subsequent conversion to rose oxide (15).

Demuth and co-workers have developed simple flatbed reactors for solar photochemical and -thermal operations in countries with largely diffuse solar radiation [89,90]. Several models of these low-tech/low-price Universal Light Collector and Reactors (ULCR) were constructed and subsequently tested for a range of photochemical transformations. The simple ULCR-1T model (Figure 4a) was built from an aluminum frame and a reflective stainless-steel bottom plate with a Teflon ${ }^{\circledR}$ cover foil (transparency $>300 \mathrm{~nm}$ ). The reactor was placed horizontally on the ground and carried inlet and outlet ports on the side of the frame, a gas inlet, a pressure release valve and optional water cooling. The more advanced and larger ULCR-4P (Figure $4 \mathrm{~b}$ ) was made from Plexiglas ${ }^{\circledR}$ (poly(methyl 2methylpropenoate), PMMA), which has a good light transparency of $>300 \mathrm{~nm}$. The reactor had an aperture of $1.5 \mathrm{~m}^{2}(98 \mathrm{~W} \times 165 \mathrm{H} \mathrm{cm})$, a thickness of $1.5 \mathrm{~cm}$ and a volume of approx. $20 \mathrm{~L}$. An inlet port for gases and additional inlet and outlet ports for reagents were attached at the top of the reactor. The gas-feeding tube ran down the inside of the reactor's body with a perforated end along its bottom. During operation, the whole device was positioned in the north-south direction and tilted to approximately $45^{\circ}$. The alternative ULCR-4M model (not shown) was made from more chemically inert twin-walled Makrolon ${ }^{\circledR}$ (poly- 
carbonate, PC). This material shows a lower light transparency of $>400 \mathrm{~nm}$, which makes it beneficial for solar transformations that do not require or are sensitive to the UV fraction of sunlight.

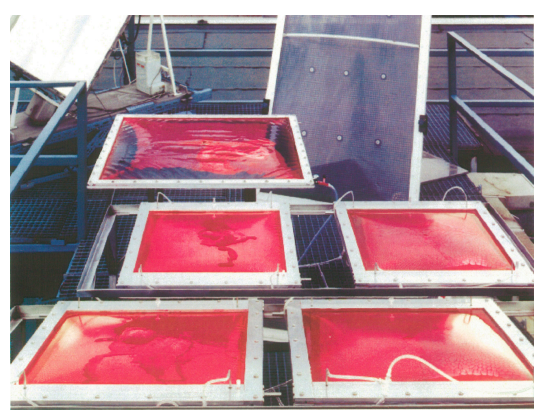

(a)

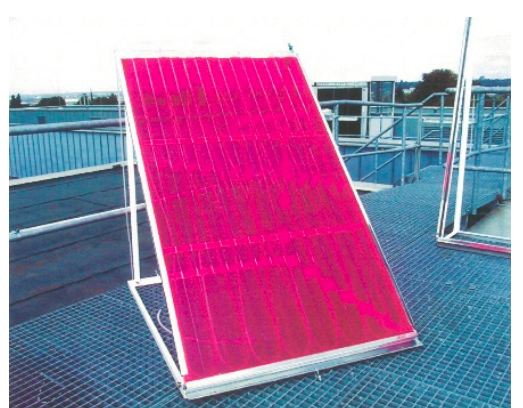

(b)

Figure 4. Examples of flatbed reactors developed by Prof Martin Demuth at the former Max Planck Institute for Radiation Chemistry in Mühlheim/Ruhr, Germany, between 1998-2000 (taken from [90]). (a) Horizonal ULCR-1T reactors. (b) Tilted ULCR-4P reactors.

Selected reactor models were subsequently used for the rose bengal-sensitized photooxygenation of citronellol (12) in methanol (Table 1). Using the horizontal ULCR-1T reactor, solar exposure of a $6.75 \mathrm{M}$ solution of $\mathbf{1 2}$ for 3 days under partially cloudy conditions, followed by thermal conversions, furnished rose oxide (15) in an isolated yield of $50 \%$ (reaction 1). In a different, not specified device made from two individual reactors connected in series, circulation of a $1.1 \mathrm{M}$ solution of $\mathbf{1 2}$ for $11 \mathrm{~h}$ under mainly cloudy conditions gave complete conversion and, after further treatment, rose oxide (15) was isolated in 52\% yield (reaction 2). For comparison, reactions 3 and 4 in a non-specified flatbed reactor were conducted in parallel in a parabolic trough reactor of a similar size (aperture of $1 \mathrm{~m}^{2}$ ) [90]. Under mainly cloudy and thus diffuse radiation conditions (reaction 3), the concentrating solar trough reactor produced a poor conversion of $\mathbf{1 2}$ of just about $25 \%$ after $11 \mathrm{~h}$ of exposure, whereas the flatbed device showed near complete consumption of citronellol (12). Under sunny conditions (reaction 4), both reactor systems performed equally well and effectively reached full conversions of $\mathbf{1 2}$ after $8 \mathrm{~h}$ of illumination. The latter two experiments demonstrated the superiority of the flatbed technology under nonideal solar conditions with predominantly diffuse radiation. In all cases, the rose oxide (15) mixtures obtained were identical in quality to those produced from reactions using artificial light.

Table 1. Experimental details of photooxygenations of citronellol (12) conducted in flatbed reactors.

\begin{tabular}{|c|c|c|c|c|}
\hline & Reaction 1 [89] & Reaction 2 [89] & Reaction 3 [90] & Reaction 4 [90] \\
\hline citronellol (12) & $0.5 \mathrm{~L}(2.7 \mathrm{~mol})$ & $0.2 \mathrm{~L}(1.1 \mathrm{~mol})$ & $0.1 \mathrm{~L}(0.55 \mathrm{~mol})$ & $0.1 \mathrm{~L}(0.55 \mathrm{~mol})$ \\
\hline methanol & $400 \mathrm{~mL}$ & $1 \mathrm{~L}$ & $2 \mathrm{~L}$ & $2 \mathrm{~L}$ \\
\hline rose bengal $^{1}$ & $5 \times 6 g$ & $3 g+1 g$ & $5 \mathrm{~g}$ & $5 \mathrm{~g}$ \\
\hline reactor & batch $\left(1 \mathrm{~m}^{2}\right)$ & in series $\left(1 \mathrm{~m}^{2}\right)$ & batch $\left(1 \mathrm{~m}^{2}\right)$ & batch $\left(1 \mathrm{~m}^{2}\right)$ \\
\hline operation & static & flow $(2 \mathrm{~L} / \mathrm{h})$ & static & static \\
\hline time & 3 days & $11 \mathrm{~h}$ & $11 \mathrm{~h}$ & $7 \mathrm{~h}$ \\
\hline solar conditions & $\begin{array}{l}50 \% \text { cloudy, } \\
50 \% \text { sunny }\end{array}$ & $\begin{array}{l}70 \% \text { cloudy; } \\
30 \% \text { sunny }\end{array}$ & $\begin{array}{l}70 \% \text { cloudy; } \\
30 \% \text { sunny }\end{array}$ & $100 \%$ sunny \\
\hline yield of $15^{2}$ & $50 \%(1.36 \mathrm{~mol})$ & $52 \%(0.57 \mathrm{~mol})$ & not reported ${ }^{3}$ & not reported ${ }^{3}$ \\
\hline
\end{tabular}

\footnotetext{
${ }^{1}$ Added in several dosages. ${ }^{2}$ Isolated yield based on 12 after further reduction and cyclization. ${ }^{3}>95 \%$ conversion of 12 .
} 
Technical-scale photooxygenations of citronellol (12) have been conducted in the advanced PROPHIS loop (Figure 1c). [59,91]. Its Helioman module comprised of four parabolic troughs equipped with Pyrex glass tubes (length $4.5 \mathrm{~m}$; inner diameter $55 \mathrm{~mm}$ ) in their focal lines. The troughs could be connected in series or in parallel. The entire concentrator had a total aperture of $32 \mathrm{~m}^{2}$ with 8 elements per trough. The individual mirror elements of $1 \mathrm{~m}^{2}$ each were made of silver-coated glass, which does not reflect any UV-light. Depending on the desired application, alternative aluminum or holographic reflectors with different reflective profiles could be fitted instead $[92,93]$. The reactor had a sunlight concentration factor of 30-32 suns and tracked the sun three-dimensionally with an advanced two-axis system during operation. Depending on the number of troughs employed, the operation volume ranged from 35 to $120 \mathrm{~L}$. The reaction reservoir, pump, heat exchanger and gas-feeding equipment were placed in a nearby shed. Solar exposures were conducted on two different technical scales (Table 2). Isopropanol was chosen as a nonhazardous solvent and oxygen gas was injected into the reagent stream, the later circulating at $30 \mathrm{~L} / \mathrm{min}$. The first experiment (reaction 5) conducted with one trough rapidly consumed $31.8 \mathrm{~mol}$ of $\mathbf{1 2}$ within three hours of solar exposure. Subsequent reduction with aqueous sodium sulfite $\left(\mathrm{Na}_{2} \mathrm{SO}_{3}\right)$ furnished the regioisomeric diols 14a and $\mathbf{b}$ in a ratio of 55:45 (by GC). The second run (reaction 6) utilized all 4 troughs under optimal solar conditions and almost completely converted $43.9 \mathrm{~mol}$ of citronellol (12) within just $2 \frac{1}{4} \mathrm{~h}$. After further thermal reduction and cyclization, rose oxide (15) was isolated in excellent quality and yield of $55 \%$. When the PROPHIS loop was equipped with a modified receiver tube that narrowed from 5 to $4.2 \mathrm{~cm}$ in inner diameter, the photooxygenation of $\mathbf{1 2}$ proceeded somewhat faster (reaction 7) than in the experiment with an unmodified tube (reaction 8) [94]. Although the overall reaction times were similar, the reaction conducted with the modified tube consumed $12.8 \mathrm{~mol}$ of $\mathbf{1 2}$ after one hour of illumination, compared to $10.5 \mathrm{~mol}$ of $\mathbf{1 2}$ with the standard tube. This improvement was explained by a better mixing that compensated for the depletion of oxygen along the narrowing tube.

Table 2. Experimental details of photooxygenations of $\mathbf{1 2}$ conducted in the PROPHIS loop.

\begin{tabular}{|c|c|c|c|c|}
\hline & Reaction 5 [91] & Reaction 6 [91] & Reaction 7 [94] & Reaction 8 [94] \\
\hline citronellol (12) & $5.8 \mathrm{~L}(31.8 \mathrm{~mol})$ & $8 \mathrm{~L}(43.9 \mathrm{~mol})$ & $5.8 \mathrm{~L}(31.8 \mathrm{~mol})$ & $5.8 \mathrm{~L}(31.8 \mathrm{~mol})$ \\
\hline isopropanol & $40 \mathrm{~L}$ & $72 \mathrm{~L}$ & $40 \mathrm{~L}$ & $40 \mathrm{~L}$ \\
\hline rose bengal & $20 \mathrm{~g}^{1}$ & $36 \mathrm{~g}^{1}$ & $2 \mathrm{~g}$ & $2 \mathrm{~g}$ \\
\hline $\mathrm{O}_{2}$-flow & $600 \mathrm{~L} / \mathrm{h}$ & $200 \mathrm{~L} / \mathrm{h}$ & not reported & not reported \\
\hline \# of troughs & $1\left(8 \mathrm{~m}^{2}\right)$ & $4\left(32 \mathrm{~m}^{2}\right)$ & $1\left(8 \mathrm{~m}^{2}\right)^{2}$ & $1\left(8 \mathrm{~m}^{2}\right)$ \\
\hline time $^{3}$ & $3 \mathrm{~h}$ & $2 \frac{1}{4} \mathrm{~h}$ & $2^{1 / 3} \mathrm{~h}$ & $2 \frac{1}{4} \mathrm{~h}$ \\
\hline solar conditions & largely sunny & $\begin{array}{c}4 \\
\text { sunny }\end{array}$ & sunny & $\begin{array}{l}4 \\
\text { sunny }\end{array}$ \\
\hline conversion of $\mathbf{1 2}{ }^{4}$ & $>95 \%$ & $>95 \%\left(55 \%{ }^{5}\right)$ & $>95 \%$ & $>95 \%$ \\
\hline
\end{tabular}

${ }^{1}$ Added in several dosages. ${ }^{2}$ Modified tube with narrowing diameter. ${ }^{3}$ Time until maximum conversion was reached. ${ }^{4}$ Determined by GC (vs. internal standard) after reduction with $\mathrm{Na}_{2} \mathrm{SO}_{3} \cdot{ }^{5}$ Isolated yield of $\mathbf{1 5}$ based on 12 after further reduction and cyclization.

To reduce heat-up and hence cooling-water needs, holographic mirrors were furthermore considered for solar photooxygenations [92,93]. These advanced reflectors were adapted to the sensitizer rose bengal with a reflectivity range of 480-620 nm. One trough of the PROPHIS loop was subsequently fitted with a holographic concentrator (Figure 5a). Due to difficulties with the stability of the holographic film, no experimental results have been reported publicly. Preliminary warm-up tests were, however, successfully completed in a smaller custom-built laboratory reactor with an aperture of $0.188 \mathrm{~m}^{2}(20 \times 94 \mathrm{~cm})$ and fitted with either aluminum or holographic elements (Figure 5b) [92]. During the experiments, a solution of rose bengal $(0.4 \mathrm{~g} / \mathrm{L})$ in isopropanol was passed through the loop at a flow rate of $60 \mathrm{~mL} / \mathrm{min}$ and the temperature differences between in- and outlet of the receiver tube were recorded. In comparison with the holographic mirror, the heat-up during illumination using the aluminum reflector was $60 \%$ higher due to the significant energy input of infrared radiation. Despite these encouraging results, experimental findings on the preparative photooxygenation of $\mathbf{1 2}$ in this device have not been published. 


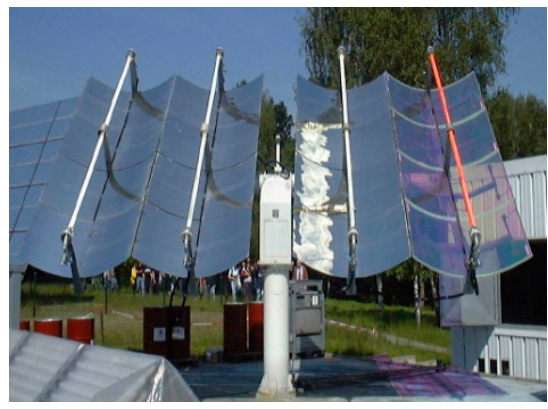

(a)

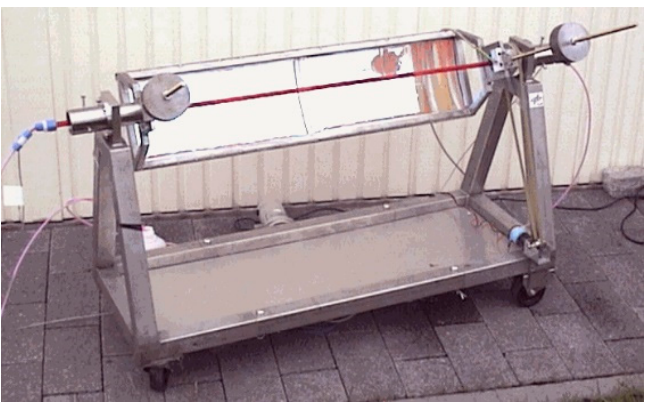

(b)

Figure 5. Parabolic trough concentrators equipped with holographic mirror elements at the German Aerospace Center (DLR) in Cologne-Porz, Germany. (a) Former PROPHIS loop, around 2002 (taken from [39]). (b) Custom-built laboratory reactor, around 1998 (taken from [92]).

Due to its technical importance [54,55], the photooxygenation of citronellol (12) was chosen for a reactor comparison study [39,41]. Next to the advanced PROPHIS concentrator (Figure 1c), four additional non-concentrating reactor systems of different volumes, apertures, concentration factors, operation modes and oxygen feeding systems were examined (Table 3). The devices were tilted at $51^{\circ}$ but did not follow the movement of the sun. The CPC system (Figure 6a) consisted of 8 rows of tubes that ran horizontally across three compartments and were connected in series via U-turn pipes. The flatbed reactor (Figure 6b) was an improved ULCR-4M model constructed from a triple walled Makrolon ${ }^{\circledR}$ sheet. A cooling tube ran through its vertical chambers and a perforated gas-feeding tube along its bottom. The horizontal tube system (Figure 6c) was made from 10 parallel glass tubes connected in series via U-turn pipes. The vertical tube reactor (Figure 6d) was constructed from 10 glass tubes in parallel that were fed from an inlet tube on the bottom.

Table 3. Reactor and experimental details of the solar campaign.

\begin{tabular}{|c|c|c|c|c|c|}
\hline & Reactions 9 & Reactions 10 & Reactions 11 & Reactions 12 & Reactions 13 \\
\hline reactor & PROPHIS & $\mathrm{CPC}$ & flatbed & horizontal tubes & vertical tubes \\
\hline CF & 32 suns & 1 sun & 1 sun & 1 sun & 1 sun \\
\hline aperture & $32 \mathrm{~m}^{2}$ & $3 \mathrm{~m}^{2}$ & $1.5 \mathrm{~m}^{2}$ & not given & not given \\
\hline volume & $80 \mathrm{~L}\left(37 \mathrm{~L}^{1}\right)$ & $40 \mathrm{~L}\left(26 \mathrm{~L}^{1}\right)$ & $21 \mathrm{~L}^{1}$ & $25 \mathrm{~L}\left(11 \mathrm{~L}^{1}\right)$ & $20 \mathrm{~L}_{\left(10 \mathrm{~L}^{1}\right)}$ \\
\hline operation & circulation & circulation & static & circulation & circulation \\
\hline mixing & static mixer & $7 \times 180^{\circ}$ turns & air bubbling & $9 \times 180^{\circ}$ turns & air bubbling \\
\hline citronellol (12) & $8 \mathrm{~L}(43.9 \mathrm{~mol})$ & $4 \mathrm{~L}(22 \mathrm{~mol})$ & $2.1 \mathrm{~L}(11.5 \mathrm{~mol})$ & $2.5 \mathrm{~L}(13.7 \mathrm{~mol})$ & $2 \mathrm{~L}(11 \mathrm{~mol})$ \\
\hline isopropanol & $72 \mathrm{~L}$ & $36 \mathrm{~L}$ & $18.9 \mathrm{~L}$ & $22.5 \mathrm{~L}$ & $18 \mathrm{~L}$ \\
\hline rose bengal 2 & $40 \mathrm{~g}$ & $20 \mathrm{~g}$ & $10.5 \mathrm{~g}$ & $12.5 \mathrm{~g}$ & $10 \mathrm{~g}$ \\
\hline $\mathrm{O}_{2}$ source & oxygen & air & air & air & air \\
\hline $\begin{array}{c}\text { time } \\
\text { (sunny/cloudy) }\end{array}$ & $\begin{array}{c}2 \frac{1}{2} \mathrm{~h}^{3} / \text { not } \\
\text { operated }\end{array}$ & $7 \mathrm{~h} / 30 \mathrm{~h}$ & $15 \mathrm{~h} / 30 \mathrm{~h}$ & $12 \mathrm{~h} / 33 \mathrm{~h}$ & $13 \mathrm{~h} / 33 \mathrm{~h}$ \\
\hline conversion of $\mathbf{1 2}{ }^{5}$ & $\begin{array}{c}>95 \%{ }^{3} / \text { not } \\
\text { operated }\end{array}$ & $>95 \% />95 \%$ & $>95 \% />95 \%$ & $>95 \% />65 \%$ & $>95 \% />65 \%$ \\
\hline
\end{tabular}

\footnotetext{
${ }^{1}$ Exposed volumes (all tubes). ${ }^{2}$ Added in several dosages. ${ }^{3}$ Reaction 6 from Table $2 .{ }^{4}$ Illumination time under sunny/cloudy conditions.

${ }^{5}$ Determined by GC (vs. internal standard) after subsequent reduction with $\mathrm{Na}_{2} \mathrm{SO}_{3}$.
} 


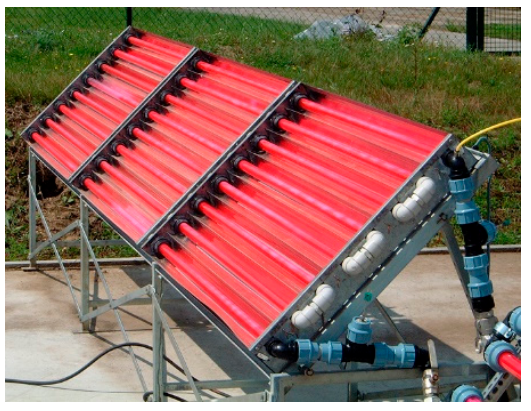

(a)

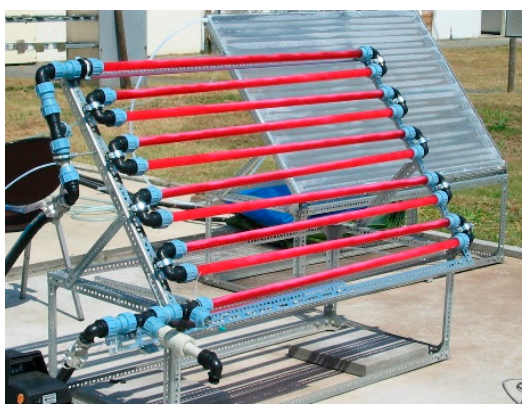

(c)

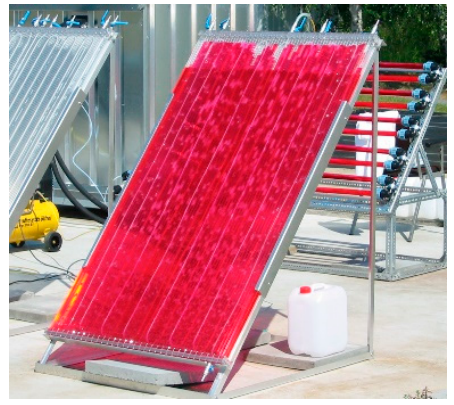

(b)

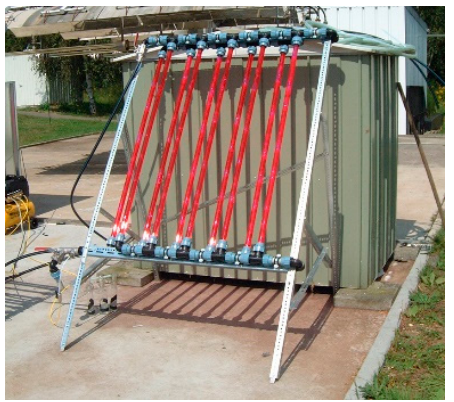

(d)

Figure 6. Solar reactors (except PROPHIS loop) used for photooxygenations of citronellol (12) at the German Aerospace Center (DLR) in Cologne-Porz, Germany in 2002. (a) CPC reactor. (b) Flatbed made from Makrolon ${ }^{\circledR}$. (c) Horizontal serial tube reactor. (d) Parallel vertical tube reactor.

The horizontal and vertical tube models had no sunlight concentrator and thus solely relied on solar radiation hitting the surface of the glass tubes. Each reactor was loaded with a $10 \mathrm{vol} \%$ solution of $\mathbf{1 2}$ in isopropanol containing $0.5 \mathrm{~g} / \mathrm{L}$ of rose bengal. Under ideal sunny conditions (Table 3 ), all reactors reached complete conversions after $2.5 \mathrm{~h}$ (PROPHIS) to $15 \mathrm{~h}$ (flatbed), respectively. Due to their superior oxygen feeding systems and hence improved oxygen saturation, the CPC and the horizontal tube device gave the highest conversion based on exposure time and illuminated area values. The PROPHIS loop showed only an average value due to its somewhat simpler oxygen supply mechanism, which only allowed gas feeding at the bottom of the first trough with relatively large oxygen bubbles formed. The poorer efficiencies of the flatbed and vertical tube reactors were explained by the inefficient gas saturation throughout these devices. Especially the compartmentalized structure of the flatbed reactor with several front and back chambers significantly limited an effective mixing and gas distribution. However, its performance could be substantially improved by operation in a circulation mode with a pump. Under less favorable cloudy conditions (Table 3), the CPC and flatbed reactors achieved complete conversions after $30 \mathrm{~h}$ of exposure over 4 days. In contrast, both the horizonal and the vertical tube reactors gave incomplete conversions of $66 \%$ at the end of the campaign after $33 \mathrm{~h}$. The sophisticated design of the СРC concentrator and the large, fully exposed aperture of the flatbed were considered beneficial and gave superior conversions based on time and area. The small surface areas of the tube reactors naturally prevented an efficient harvesting of diffuse sunlight. The PROPHIS loop was not used under cloudy conditions due to its dependence on direct solar radiation.

An economic evaluation study for the manufacturing of rose oxide (15) on a $100 \mathrm{t} /$ year scale in Germany has been described by Monnerie and Ortner [95]. For this, initial investment and subsequent operation costs for solar vs. lamp-driven photooxygenation processes were compared and assessed. The study suggested that the solar operation was significantly more profitable. 
Dincalp and Icli investigated diimide-sensitized photooxidations of (-)-citronellol (12) in concentrated sunlight at 90-100 suns (Scheme 8 and Table 4) [96]. Solar exposures were performed with acetonitrile solutions of $12(0.2 \mathrm{M})$ that were purged with air during experimental runs. Reaction mixtures were placed in a photoreactor vessel and positioned in the focal point of a dish concentrator (Figure 3). Samples were withdrawn during or after illumination and, after further thermal reduction with $\mathrm{Na}_{2} \mathrm{SO}_{3}$, were analyzed by GC-MS.

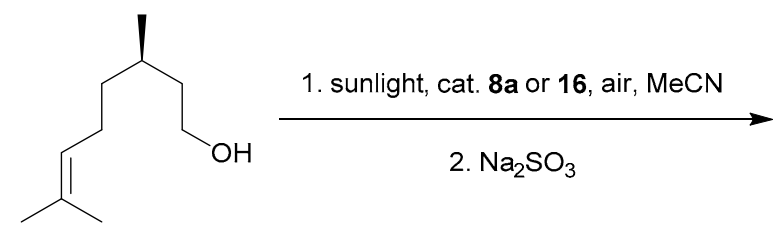

$(-)-12$

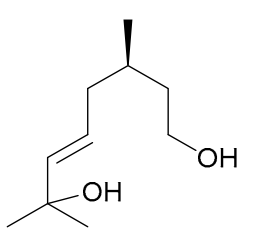

$14 a$

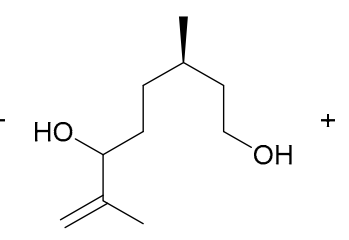

$14 b$

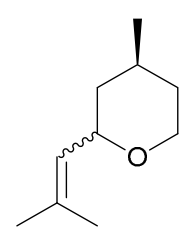

$(-)-15$

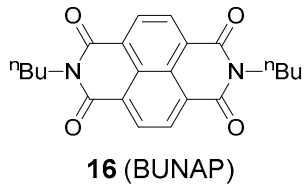

3.65 mL of (-)-12 and 1-2 $\mathrm{mg}$ of $8 \mathbf{a}$ or 16 in $\mathrm{MeCN}(100 \mathrm{~mL})$ optionally $2-5 \mathrm{mg}$ of $\mathrm{CuPiv}_{2}$ or $\mathrm{FeMyr}_{3}$

Scheme 8. Diimide-sensitized photooxidations of (-)-12 and subsequent conversions to rose oxide (15).

Table 4. Experimental details of diimide-sensitized photooxidations of (-)-12.

\begin{tabular}{|c|c|c|c|c|}
\hline & Reaction 14 & Reaction 15 & Reaction 16 & Reaction 17 \\
\hline sensitizer & ABIPER (8a) & BUNAP (16) & ABIPER (8a) & ABIPER (8a) \\
\hline additive & none & none & $\mathrm{CuPiv}_{2}$ & $\mathrm{FeMyr}_{3}$ \\
\hline exposure time $^{1}$ & $2 \mathrm{~h}$ & $1 \mathrm{~h}$ & $2 \mathrm{~h}$ & $2 \mathrm{~h}$ \\
\hline residual $12^{2}$ & $3 \%$ & $1 \%$ & $81 \%$ & $36 \%$ \\
\hline $14 a / 14 b^{2}$ & $6 \%$ & $20 \%$ & $2 \%$ & $5 \%$ \\
\hline $15\left(\text { cis } / \text { trans }^{3}\right)^{2}$ & $76 \% / 6 \%$ & $54 \% / 23 \%$ & $11 \% / 5 \%$ & $53 \% / 6 \%$ \\
\hline
\end{tabular}

${ }^{1}$ Maximum exposure times. ${ }^{2}$ Determined by GC after subsequent reduction with $\mathrm{Na}_{2} \mathrm{SO}_{3} .{ }^{3}$ Diasteroisomers.

Using ABIPER (8a) as a photosensitizer (reaction 14), the conversion of (-)-citronellol (12) increased with prolonged illumination and after $2 \mathrm{~h}$, rose oxide $\mathbf{1 5}$ was obtained as a diastereoisomeric mixture in a total amount of ca. $82 \%$, next to the regioisomeric diols $14 \mathbf{a}$ and $\mathbf{b}$ and residual $\mathbf{1 2}$ with approx. $6 \%$ and $3 \%$, respectively. When the naphthalene diimide sensitizer BUNAP 16 was employed (reaction 15), conversions of 12 again increased with extended exposure times. The photoproduct obtained after $1 \mathrm{~h}$ of exposure to concentrated sunlight contained ca. $77 \%$ of rose oxide (15), $20 \%$ of diols $14 \mathbf{a}$ and $\mathbf{b}$ and $1 \%$ of unreacted (-)-citronellol (12). Despite the high sunlight concentration factor, both photosensitizers remained visibly photostable throughout the experiments. In line with earlier investigations, an electron transfer mechanism involving the super oxide anion radical $\left(\mathrm{O}_{2}{ }^{\bullet-}\right)$ was postulated instead of a singlet oxygen $\left({ }^{1} \mathrm{O}_{2}\right)$ pathway. Addition of cupric pivalate $\left(\mathrm{CuPiv}_{2}\right.$; reaction 16) or ferric myristate $\left(\mathrm{FeMyr}_{3} ;\left(\mathrm{C}_{13} \mathrm{H}_{27} \mathrm{CO}_{2}\right)_{3} \mathrm{Fe}\right.$; reaction 17$)$ retarded the reaction and solar illuminations for $2 \mathrm{~h}$ reached conversions of $\mathbf{1 2}$ of just approximately $19 \%$ and $64 \%$, respectively. The diasteroisomeric ratios for cis- and trans-15 varied depending on experiment, but no reasonable explanation was given to rationalize these findings.

\subsection{Photooxygenations of $\beta$-Pinene for the Production of Myrtenol}

The Schenck ene-photooxygenation of $\beta$-pinene (17), followed by successive reduction of the hydroperoxide intermediate 18, yields myrtenol (19), with myrtenal (20) as a common by-product (Scheme 9) [97]. Myrtenol is used as a fragrance ingredient in a variety of cosmetic, household and detergent products with an annual demand of $<0.1$ tons reported in 2008 [98]. Using a modified photooxygenation procedure, myrtenal (20) can be obtained as the main product instead [99]. 


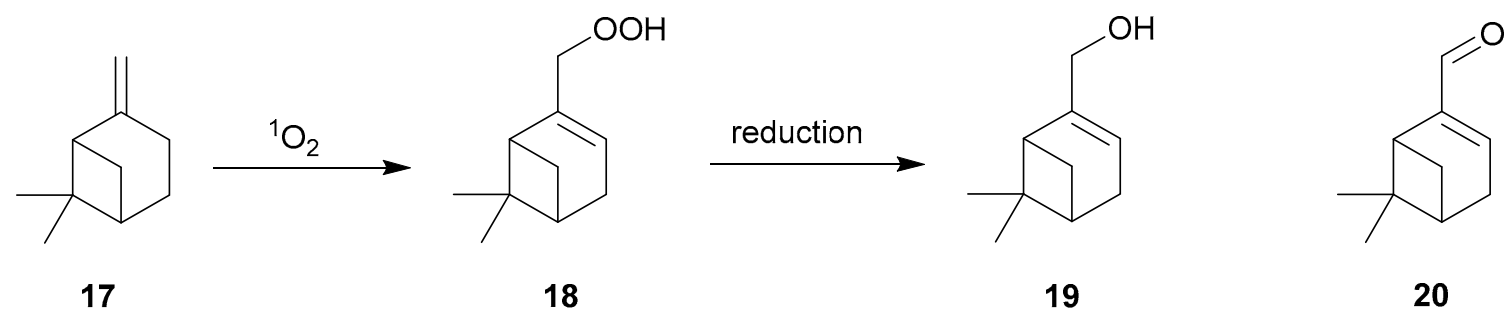

Scheme 9. Photooxygenation of $\beta$-pinene (17) and subsequent conversion to myrtenol (19).

Several solar photooxygenations of $\mathbf{1 7}$ have been independently reported and selected details are compiled in Table 5 . The rose bengal-sensitized reaction of a $5 \mathrm{vol} \%$ solution of $\beta$-pinene (17) in isopropanol has been conducted at the German Aerospace Center DLR in Germany in a CPC reactor (Figure 6a). The reaction proceeded very slowly and a conversion of $\mathbf{1 7}$ of approximately $95 \%$ was achieved only after exhaustive exposure for 9 days (reaction 18 ).

To reach higher space-time yields, the reaction was transferred to the solar furnace at the DLR (Figure 7a) [100]. In this facility, sunlight is reflected by a single sun-tracking $52 \mathrm{~m}^{2}$ heliostat onto a concentrator made from 147 spherical mirrors (aperture of $39.1 \mathrm{~m}^{2}$ ) that directs the resulting sun beam on the experimental setup inside the laboratory room [61]. Solar photooxygenations of $\mathbf{1 7}$ were performed in a specialized circulating reactor fitted with an IR-filter cell and a reaction cell, the later with a total volume of approx. $5.1 \mathrm{~L}$. An initial experiment was conducted in non-flammable chloroform under mainly sunny conditions using only 67 of the spherical mirrors (aperture of $18 \mathrm{~m}^{2}$ ) and tetraphenylporphyrine (TPP) as a sensitizer. Due to sensitizer bleaching and technical difficulties with the oxygen supply, the reaction was stopped after less than $3 \mathrm{~h}$. After reduction with thiourea, a conversion of $\mathbf{1 7}$ of approx. 30\% was determined by GC analysis. The solar reactor was consequently modified to allow for the usage of flammable solvents and a better oxygen feeding (Figure $7 \mathrm{~b}$ ). The improved device was then applied to rose bengal-sensitized photooxygenations of $\beta$-pinene (17) in ethanol. To account for possible quenching effects by breakdown products of the sensitizer rose bengal during exhaustive illumination [101], initial experiments were stopped after partial conversions of $\mathbf{1 7}$ of approx. $45 \%$ and $65 \%$, respectively. After reduction with $\mathrm{Na}_{2} \mathrm{SO}_{3}$ and aqueous workup to remove any degradation products, the crude mixtures containing unreacted 17 and myrtenol (19) were subjected to further photooxygenation. Following this approach, conversions of $97 \%$ (by GC) were achieved after $14 \mathrm{~h}$ of exposures under largely sunny conditions. The rose bengal-sensitized photooxygenation of $\mathbf{1 7}(0.52 \mathrm{M})$ under comparable conditions without interruption and in between workup also achieved near complete conversion of $97 \%$ after $14 \mathrm{~h}$ of illumination (reaction 19). Quenching or retarding effects by potential photodegradation products were thus ruled out. From this experimental run, a high space-time yield of $3.6 \times 10^{-2} \mathrm{~mol} /(\mathrm{L} \cdot \mathrm{h})$ was furthermore determined. However, the high construction, operation and maintenance costs of solar furnaces prevent their widespread application for preparative photochemistry.

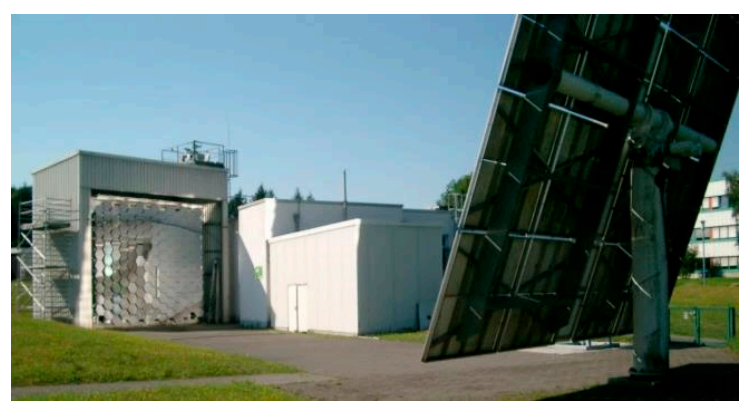

(a)

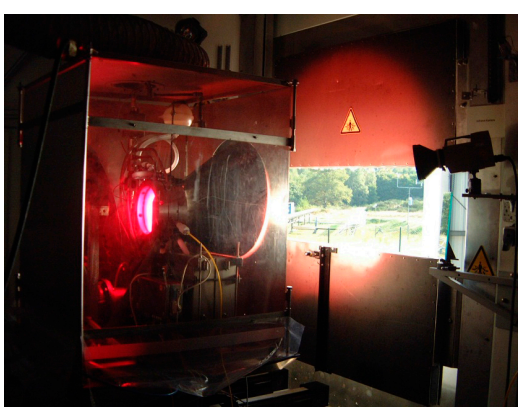

(b)

Figure 7. (a) Solar furnace at the German Aerospace Center (DLR) in Cologne-Porz, Germany, around 2005 (taken from [39]). (b) Custom-built photooxygenation reactor, around 2001 (taken from [39]). 
Table 5. Reactor and experimental details of selected solar photooxygenations of $\beta$-pinene (17).

\begin{tabular}{|c|c|c|c|}
\hline & Reaction 18 & Reaction 19 [100] & Reaction 20 [102] \\
\hline reactor & $\mathrm{CPC}$ & DLR solar furnace & SOLARIS \\
\hline CF & 1 sun & up to 4,800 suns & 20 suns $\left(42\right.$ suns $\left.^{1}\right)$ \\
\hline volume & $40 \mathrm{~L}\left(26 \mathrm{~L}^{2}\right)$ & $5.1 \mathrm{~L}\left(2.03 \mathrm{~L}^{2}\right)$ & $70 \mathrm{~L}\left(30 \mathrm{~L}^{2}\right)$ \\
\hline$\beta$-pinene (17) & $2 \mathrm{~L}(12.8 \mathrm{~mol})$ & $0.29 \mathrm{~L}(1.84 \mathrm{~mol})$ & $6.2 \mathrm{~L}(37.7 \mathrm{~mol})$ \\
\hline solvent & $38 \mathrm{~L}\left({ }^{\mathrm{i}} \mathrm{PrOH}\right)$ & $3.5 \mathrm{~L}(\mathrm{EtOH})$ & $35 \mathrm{~L}\left({ }^{\mathrm{i}} \mathrm{PrOH}\right)$ \\
\hline rose bengal & not reported & $40 \mathrm{~g}^{3}$ & $21.77 \mathrm{~g}^{3}$ \\
\hline exposure time & 9 days & $14 \mathrm{~h}$ & 3 days (ca. $27 \mathrm{~h}$ ) \\
\hline conversion of $17^{4}$ & $95 \%$ & $97 \%$ & ca. $56 \%$ \\
\hline
\end{tabular}

${ }^{1}$ Theoretical concentration factor without optical losses. ${ }^{2}$ Exposed volumes of reactor. ${ }^{3}$ Added in several dosages. ${ }^{4}$ Determined by GC directly or after subsequent reduction with $\mathrm{Na}_{2} \mathrm{SO}_{3}$.

Esser furthermore investigated the solar transformation of $\beta$-pinene (17) with moderately concentrated sunlight at the Plataforma Solar de Almería (PSA) in Spain in 1992 [102]. The experiment was conducted in the former SOLARIS (SOLAR photochemical synthesIS of fine chemicals) facility, an earlier version of the PROPHIS loop (Figure 1c) [103]. This parabolic trough reactor used aluminized polymeric film reflectors, had an effective concentration factor of 20 suns in practice (theoretical 42 suns) and an operating capacity of 35-70 L. Utilizing one trough (aperture of $7.29 \mathrm{~m}^{2}$ ), a solution of $\mathbf{1 7}$ and rose bengal (in 10 portions) in $35 \mathrm{~L}$ of isopropanol was passed through the loop at approx. $42 \mathrm{~L} / \mathrm{min}$ while oxygen was injected into the reagent stream. The reaction temperature was maintained at roughly $20^{\circ} \mathrm{C}$ and the progress of the reaction was monitored by GC analysis (reaction 20). After approximately $27 \mathrm{~h}$ of exposure over three consecutive days with good to excellent sunlight conditions, a conversion of $\beta$-pinene (17) of approx. $56 \%$ was reached, corresponding to an average conversion rate of $2.2 \% / \mathrm{h}$ (or $0.84 \mathrm{~mol} / \mathrm{h}$ ). Subsequent solar thermal reduction with aqueous sodium sulfite $\left(\mathrm{Na}_{2} \mathrm{SO}_{3}\right)$ in the SOLARIS loop furnished a crude product mixture containing ca. $40 \%$ of residual $17,44 \%$ of myrtenol (19), $7 \%$ of myrtenal (20) and $1 \%$ of hydroperoxide 18 (by GC), respectively.

\subsection{Photooxygenations of $\alpha$-Thujene for the Production of Trans-Sabinene Hydrate}

The important and valuable flavor compound trans-sabinene hydrate (24; also known as trans-4-thujanol) is synthesized industrially from $\alpha$ - or 3-thujene (21) (Scheme 10) $[55,104,105]$. Initial photooxygenation of 21 and subsequent reduction of the regioisomeric hydroperoxides $22 \mathbf{a}$ and $\mathbf{b}$ yields (-)-trans-4-hydroxy- $\beta$-thujene (23a) and (-)-cis-sabinol (23b) in a ratio of approx. 3:1. Catalytic hydrogenation of 23a produces the desired trans-sabinene hydrate (24), while alternative oxidation furnishes the naturally occurring and somewhat toxic (-)-umbellulone (25).

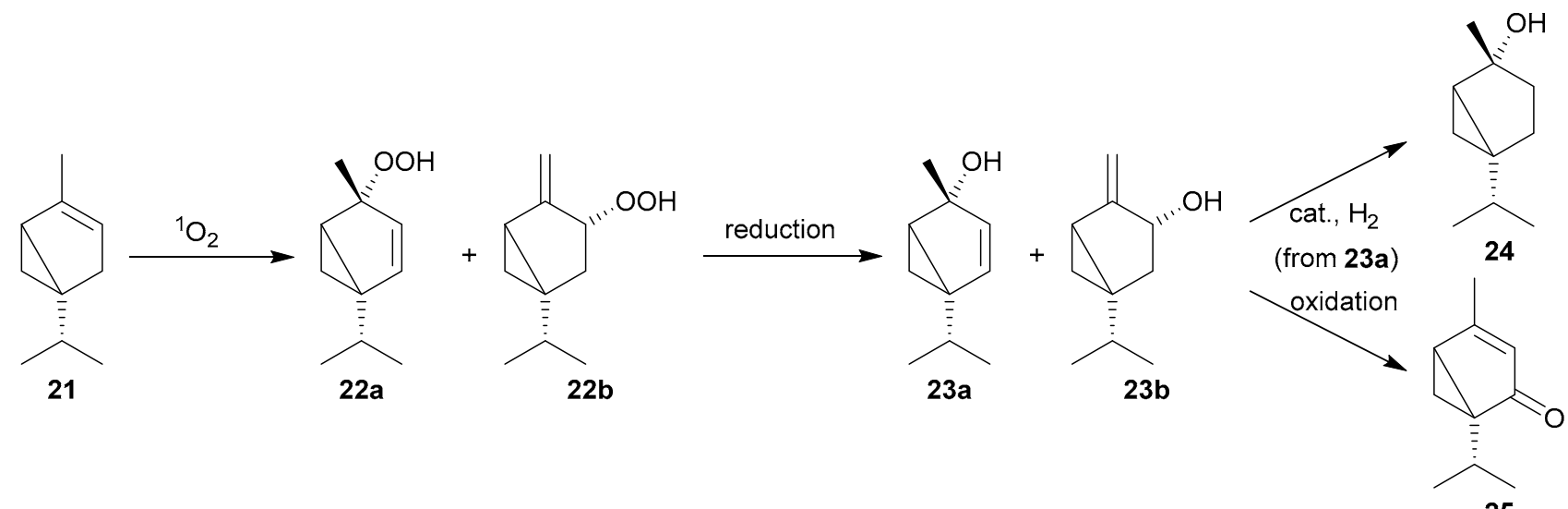

25

Scheme 10. Photooxygenation of $\alpha$-thujene (21) and subsequent conversions to trans-sabinene hydrate (24) or (-)umbellulone (25). 
In 1992, Esser conducted a series of seven solar photooxygenations of $\alpha$-thujene (21) in isopropanol in the SOLARIS reactor equipped with one trough (Figure 8 and Table 6) [102,106]. Technical grade 21, which contained $\alpha$-pinene as impurity, with a purity of ca. $87 \%$ was employed. $\alpha$-Pinene also underwent photooxygenations and its corresponding reduced photoproducts were thus detected and quantified [97]. Methylene blue (MB) or rose bengal (RB) were investigated as ${ }^{1} \mathrm{O}_{2}$ photosensitizers. Both showed significant decomposition in concentrated sunlight and hence required regular refeeding during the experiments. Depending on conversion rates and weather conditions, fluid and oxygen gas flows were adjusted between $35-45 \mathrm{~L} / \mathrm{min}$ and $1.0-5.5 \mathrm{~L} / \mathrm{min}$, respectively. For reactions $21-26$, the reaction mixtures were cooled to approximately $20{ }^{\circ} \mathrm{C}$ during circulation within the reactor loop. Only for reaction 27, the temperature was increased to approx. $30{ }^{\circ} \mathrm{C}$ instead. Based on the total solar radiation recorded, the corresponding moles of photons received in the absorption range of the respective sensitizer, and hence solar photon yields $\left(\eta_{\mathrm{s}}\right)$ were calculated. All solar photooxygenations proceeded efficiently and furnished high to near complete conversions of 21 of $>87 \%$ after exposure times of $4 \frac{1}{2}-11 \mathrm{~h}$. Due to the instability of the hydroperoxide intermediates $\mathbf{2 2} \mathbf{a}$ and $\mathbf{b}$, their subsequent solar thermal reductions were directly performed inside the SOLARIS loop at temperatures $>50{ }^{\circ} \mathrm{C}$. Except for reaction 22, high selectivities for (-)-trans-4-hydroxy- $\beta$-thujene (23a) formation of $\geq 72 \%$ were achieved. The best overall results with respect to exposure time, conversion, selectivity and solar photon yield were accomplished with rose bengal at $20{ }^{\circ} \mathrm{C}$ (reactions 25 and 26). From the combined crude product mixture of all experiments, the desired (-)-trans-4-hydroxy- $\beta$-thujene (23a) was isolated in 78\% purity (by GC) and 65\% yield, both exceeding the reported values for lamp-driven processes. This was explained by the smaller UV-content of the reflected natural sunlight.

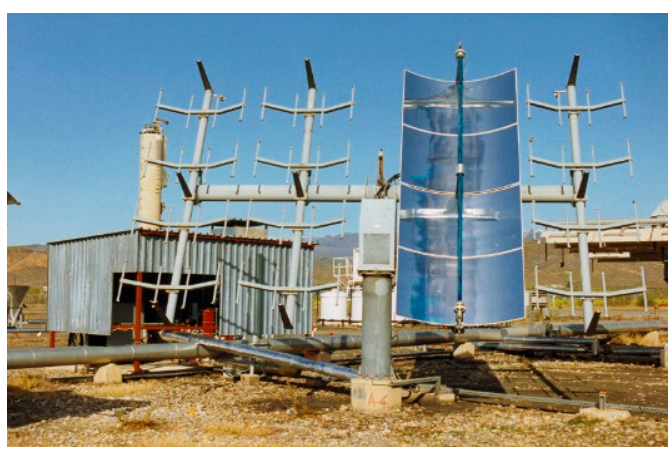

(a)

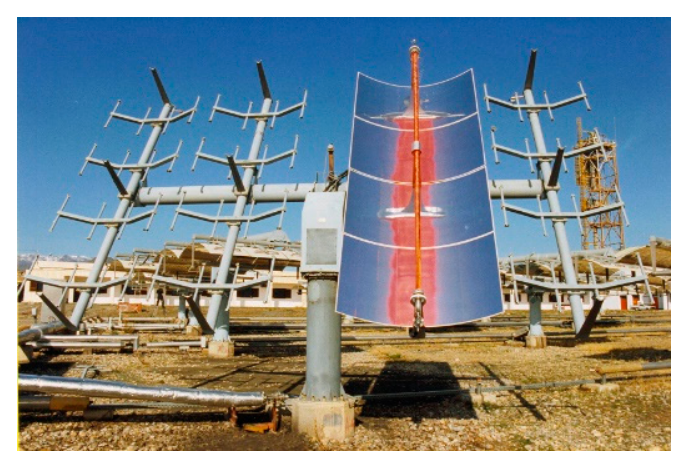

(b)

Figure 8. Former SOLARIS loop at the Plataforma Solar de Almería (PSA) near Tabernas, Spain, in 1992. (a) Used for a methylene blue and $(\mathbf{b})$ rose bengal-sensitized photooxygenation.

\subsection{Photooxygenations of Furfural and Furfuraldiethylacetal to 5-Hydroxy-and 5-Alkoxyfuranones}

The photooxygenation of furfural (26) in various alcohols was first described by Schenck, who isolated the corresponding 5-alkoxyfuranone derivatives 28 (Scheme 11) [106, 107]. It was later shown that 5-hydroxyfuranone (27) is formed as the initial photoproduct, which can be subsequently isolated in yields of $\leq 90 \%[108,109]$. The pseudo-acid 27 is rapidly converted to 28 at elevated temperatures $>70{ }^{\circ} \mathrm{C}$, which were commonly exceeded in earlier studies. Hydroxyfuranone (27) has pesticidal properties but also serves as a versatile $\mathrm{C}_{4}$ building block in organic synthesis [110]. Longer-chain 5-alkoxyfuranones, prepared by acid-catalyzed (trans)esterification, have been described as fragrances [111]. 
Table 6. Experimental details of photooxidations of 21.

\begin{tabular}{|c|c|c|c|c|c|c|c|}
\hline & Reaction 21 & Reaction 22 & Reaction 23 & Reaction 24 & Reaction 25 & Reaction 26 & Reaction 27 \\
\hline$\alpha$-thujene & $2.7 \mathrm{~kg}$ & $5.42 \mathrm{~kg}$ & $5.45 \mathrm{~kg}$ & $\sim 3.3 \mathrm{~kg}$ & $5.63 \mathrm{~kg}$ & $5.64 \mathrm{~kg}$ & $5.63 \mathrm{~kg}$ \\
\hline$(21)^{1}$ & $(17.2 \mathrm{~mol})$ & $(34.5 \mathrm{~mol})$ & (34.6 mol) & $(20.9 \mathrm{~mol})$ & $(35.8 \mathrm{~mol})$ & (35.9 mol) & (35.8 mol) \\
\hline${ }^{\mathrm{i}} \mathrm{PrOH}$ & $44 \mathrm{~L}$ & $38 \mathrm{~L}$ & $35 \mathrm{~L}$ & $\sim 32 \mathrm{~L}$ & $35 \mathrm{~L}$ & $35 \mathrm{~L}$ & $35 \mathrm{~L}$ \\
\hline sensitizer $^{2}$ & $\begin{array}{l}5.26 \mathrm{~g} \\
(\mathrm{MB})\end{array}$ & $\begin{array}{l}9.61 \mathrm{~g} \\
(\mathrm{MB})\end{array}$ & $\begin{array}{l}11.11 \mathrm{~g} \\
(\mathrm{MB})\end{array}$ & $\begin{array}{c}12.29 \mathrm{~g} \\
(\mathrm{MB})\end{array}$ & $\begin{array}{c}12.82 \mathrm{~g} \\
(\mathrm{RB})\end{array}$ & $\begin{array}{c}9.02 \mathrm{~g} \\
(\mathrm{RB})\end{array}$ & $\begin{array}{l}6.95 \mathrm{~g} \\
(\mathrm{RB})\end{array}$ \\
\hline time $^{3}$ & $\begin{array}{c}\sim 7 \mathrm{~h} \\
\text { (1 day) }\end{array}$ & $\begin{array}{c}\sim 11 \mathrm{~h} \\
\text { (2 days) }\end{array}$ & $\begin{array}{c}7 \mathrm{~h} \\
\text { (1 day) }\end{array}$ & $\begin{array}{c}\sim 7 \mathrm{~h} \\
\text { (1 day) }\end{array}$ & $\begin{array}{c}6 \mathrm{~h} \\
\text { (1 day) }\end{array}$ & $\begin{array}{c}5 \frac{1}{2} \mathrm{~h} \\
\text { (1 day) }\end{array}$ & $\begin{array}{c}4 \frac{1}{2} \mathrm{~h} \\
\text { (1 day) }\end{array}$ \\
\hline total radiation 4 & $\begin{array}{l}16.5 \mathrm{kWh} \\
(110 \mathrm{~mol})\end{array}$ & $\begin{array}{l}37.9 \mathrm{kWh} \\
(271 \mathrm{~mol})\end{array}$ & $\begin{array}{l}40.8 \mathrm{kWh} \\
(287 \mathrm{~mol})\end{array}$ & $\begin{array}{l}43.0 \mathrm{kWh} \\
(306 \mathrm{~mol})\end{array}$ & $\begin{array}{l}29.9 \mathrm{kWh} \\
(123 \mathrm{~mol})\end{array}$ & $\begin{array}{l}27.5 \mathrm{kWh} \\
(113 \mathrm{~mol})\end{array}$ & $\begin{array}{l}24.2 \mathrm{kWh} \\
(106 \mathrm{~mol})\end{array}$ \\
\hline$\eta_{\mathrm{s}}{ }^{5}$ & $14 \%$ & $12 \%$ & $12 \%$ & $7 \%$ & $29 \%$ & $31 \%$ & $33 \%$ \\
\hline conversion ${ }^{6}$ & $88 \%$ & $97 \%$ & $96 \%$ & $97 \%$ & $\sim 100 \%$ & $99 \%$ & $98 \%$ \\
\hline $21^{7}$ & $12 \%$ & $2 \%$ & $3 \%$ & $2 \%$ & $<1 \%$ & $1 \%$ & $1 \%$ \\
\hline $23 a^{7}$ & $61 \%$ & $56 \%$ & $63 \%$ & $66 \%$ & $65 \%$ & $67 \%$ & $61 \%$ \\
\hline $23 b^{7}$ & $7 \%$ & $11 \%$ & $11 \%$ & $10 \%$ & $10 \%$ & $11 \%$ & $13 \%$ \\
\hline selectivity $^{8}$ & $82 \%$ & $67 \%$ & $75 \%$ & $78 \%$ & $75 \%$ & $78 \%$ & $72 \%$ \\
\hline
\end{tabular}

${ }^{1}$ Technical grade (86.5\%). ${ }^{2}$ Sensitizer added in several dosages. ${ }^{3}$ Illumination time (over number of days). ${ }^{4}$ Calculated molar radiation up to $700 \mathrm{~nm}(\mathrm{MB})$ or $600 \mathrm{~nm}$ (RB). ${ }^{5}$ Solar photon yield. ${ }^{6}$ Conversion of 21 by GC. ${ }^{7}$ Product composition by GC after reduction with $\mathrm{Na}_{2} \mathrm{SO}_{3}$ (by-products excluded). ${ }^{8}$ Selectivity for $23 \mathrm{a}$.<smiles>O=Cc1ccco1</smiles>

26

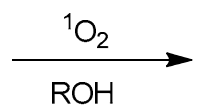

27<smiles>O=C1C=C[C@@H](O)O1</smiles>

27

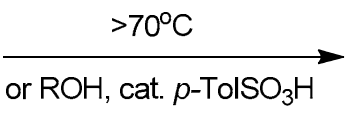

or $\mathrm{ROH}$, cat. $p$ - $\mathrm{TolSO}_{3} \mathrm{H}$

28

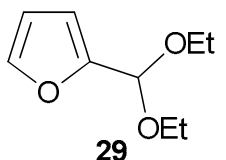

29

Scheme 11. Photooxygenation of furfural (26) to 5-hydroxyfuranone (27) and subsequent conversion to 5-alkoxyfuranones (28).

The solar exposure of a solution of $\mathbf{2 6}(100 \mathrm{~g})$ and eosin $(1 \mathrm{~g})$ in ethanol $(1 \mathrm{~L})$ in a large conical flask has been described in a patent in 1953 [108]. After $1 \frac{1}{2}$ days in direct sunlight, 5-ethoxyfuranone (28; $\mathrm{R}=\mathrm{Et})$ was isolated in a yield of 50\% $(66.7 \mathrm{~g})$.

In 1991 and 1992, sixteen large-scale photooxygenations were subsequently investigated in the SOLARIS loop equipped with a single trough (Figure 8) [47,102]. Process conditions were systematically varied and included alterations in the starting material (26 vs. 29), photosensitizer (RB vs. MB), temperature, fluid flow rates and possible additives. Five selected examples from this solar campaign are summarized in Table 7 [47]. The oxygen gas flow rates were adjusted based on the weather conditions and reaction progress and ranged between 0.7 and $5.5 \mathrm{~L} / \mathrm{min}$. Methylene blue was identified as the preferred photosensitizer due to its superior stability under the weakly acidic reaction conditions. Despite varying weather conditions, all solar reactions furnished near complete conversions of $>95 \%$ after $3 \frac{1}{4}-16 \mathrm{~h}$ of illumination. The reaction was found to be very robust and partially converted reaction mixtures could be kept in the reactor loop during bad weather periods. The addition of concentrated hydrochloric acid (reaction 31) was found beneficial due to the rapid formation of furfuraldiethylacetal (29), which reacted more rapidly with singlet oxygen than furfural (26) itself. This was demonstrated when diethylacetal 29 was used as the starting material (reaction 32). While the selectivity for the formation of hydroxyfuranone (27) was high during the actual photooxygenation, significant conversion into ethoxyfuranone $(28 ; \mathrm{R}=\mathrm{Et})$ occurred during further workup and isolation. No attempts to isolate the more desirable $\mathbf{2 7}$ from these mixtures were consequently made. However, the acid-catalyzed (trans)esterification of a crude mixture (ca. $250 \mathrm{~g})$ containing 27 and $28(\mathrm{R}=\mathrm{Et})$ with $n$-hexanol to hexyloxyfuranone $(\mathbf{2 8} ; \mathrm{R}=\mathrm{Hex})$ in $79 \%$ yield has been reported in a patent [111]. 
Table 7. Experimental details of selected photooxidations of furane derivatives 26 and 29.

\begin{tabular}{|c|c|c|c|c|c|}
\hline & Reaction 28 & Reaction 29 & Reaction 30 & Reaction 31 & Reaction 32 \\
\hline \multirow{2}{*}{ furane } & $2.06 \mathrm{~kg}$ & $2.14 \mathrm{~kg}$ & $4.32 \mathrm{~kg}$ & $3.61 \mathrm{~kg}$ & $3.61 \mathrm{~kg}$ \\
\hline & $21.5 \mathrm{~mol} \mathrm{(26)}$ & $22.3 \mathrm{~mol} \mathrm{(26)}$ & $45.0 \mathrm{~mol} \mathrm{(26)}$ & $37.6 \mathrm{~mol} \mathrm{(26)}$ & $21.2 \mathrm{~mol}(29)$ \\
\hline ethanol & $35 \mathrm{~L}$ & 35 & 30 & 35 & 35 \\
\hline sensitizer ${ }^{1}$ & $6.1 \mathrm{~g}(\mathrm{MB})$ & $11.2 \mathrm{~g}(\mathrm{RB})$ & $5.1 \mathrm{~g}(\mathrm{MB})$ & $9.0 \mathrm{~g}(\mathrm{MB})$ & $6.0 \mathrm{~g}(\mathrm{MB})$ \\
\hline additive & none & none & none & c. $\mathrm{HCl}(5 \mathrm{~mL})$ & none \\
\hline temperature & $8^{\circ} \mathrm{C}$ & $20^{\circ} \mathrm{C}$ & $20^{\circ} \mathrm{C}$ & $20^{\circ} \mathrm{C}$ & $20^{\circ} \mathrm{C}$ \\
\hline fluid flow & $35 \mathrm{~L} / \mathrm{min}$ & $55 \mathrm{~L} / \mathrm{min}$ & $55 \mathrm{~L} / \mathrm{min}$ & $45 \mathrm{~L} / \mathrm{min}$ & $45 \mathrm{~L} / \mathrm{min}$ \\
\hline time $^{2}$ & $\begin{array}{c}16 \mathrm{~h} \\
\text { (3 days) }\end{array}$ & $\begin{array}{c}\sim 11 \mathrm{~h} \\
\text { (2 days) }\end{array}$ & $\begin{array}{l}\sim 12 \frac{1}{2} \mathrm{~h} \\
\text { (2 days) }\end{array}$ & $\begin{array}{c}5 \frac{1}{2} \mathrm{~h} \\
\text { (1 day) }\end{array}$ & $\begin{array}{c}\sim 3 \frac{1}{4} \mathrm{~h} \\
\text { (1 day) }\end{array}$ \\
\hline total & $22.2 \mathrm{kWh}$ & $54.3 \mathrm{kWh}$ & $61.9 \mathrm{kWh}$ & $32.4 \mathrm{kWh}$ & $16.9 \mathrm{kWh}$ \\
\hline radiation $^{3}$ & $140 \mathrm{~mol}$ & $413 \mathrm{~mol}$ & $436 \mathrm{~mol}$ & $226 \mathrm{~mol}$ & $114 \mathrm{~mol}$ \\
\hline$\eta_{\mathrm{s}} 4$ & $15 \%$ & $5 \%$ & $10 \%$ & $16 \%$ & $18 \%$ \\
\hline conversion ${ }^{5}$ & $98 \%$ & $99 \%$ & $\sim 100 \%$ & $98 \%$ & $95 \%$ \\
\hline $27: 28^{6}$ & $42: 1$ & $133: 1$ & $58: 1$ & $98: 1$ & $390: 1$ \\
\hline
\end{tabular}

${ }^{1}$ Sensitizer added in several dosages. ${ }^{2}$ Illumination time (over number of days). ${ }^{3}$ Calculated molar radiation up to $700 \mathrm{~nm} .{ }^{4}$ Solar photon yield. ${ }^{5}$ Conversion of 26 or 29 by GC. ${ }^{6}$ Ratio of 27 vs. 28 (R = Et) by GC.

\subsection{Photooxygenations of 1,5-Dihydroxynaphthalene to Juglone}

Juglone or 5-hydroxy-1,4-naphthoquinone (31) is a naturally occurring compound that is used as a herbicide, dye, coloring agent and versatile building block chemical [112]. It can be obtained in good yields from 1,5-dihydroxynaphthalene (30) through photooxygenation (Scheme 12) [113].<smiles>Oc1cccc2c(O)cccc12</smiles>

30<smiles>O=C1C=CC(=O)c2c(O)cccc21</smiles>

31

Scheme 12. Photooxygenation of 1,5-dihydroxynaphthalene (30) to juglone (31).

Small laboratory-scale photooxygenations of 30 (0.5-2 g) have been conducted by Oelgemöller and co-workers in custom-built parabolic trough reactors (Table 8). Initial experiments were performed in a horizontal trough reactor (Pyrex tube diameter of $1.2 \mathrm{~cm}$ ) equipped with holographic mirror elements and using isopropanol as a solvent (Figure 9a) [91]. The reactor had an optimal reflectivity range for the usage of rose bengal of 480-620 nm [92,93], aperture of $0.188 \mathrm{~m}^{2}$ and a concentration factor of approx. 15 suns. Oxygen gas was injected into the circulating reagent flow in a Y-connector, thus generating an uneven gas-liquid flow. Conversion rates of $\geq 83 \%$ were achieved after illuminations for $3 \mathrm{~h}$ and $8 \mathrm{~h}$ and juglone (31) was isolated in yields of $54 \%$ and $79 \%$, respectively (reactions 33 and 34).

Using the identical reactor equipped with a polished aluminum reflector instead, the same authors tested different solvents (isopropanol vs. acetone) and sensitizer materials (RB vs. MB; soluble vs. solid-supported) [114]. Applying a standard solution of $2 \mathrm{~g}$ of diol $\mathbf{3 0}$ in $250 \mathrm{~mL}$ of solvent and a fixed exposure time of four hours, the experiments conducted in either solvent with soluble rose bengal showed the best performances (reactions 35 and 36). Both runs achieved high conversions of $\geq 93 \%$ and furnished juglone (31) in isolated yields of $75 \%$ and $79 \%$, respectively. The solid-supported sensitizing materials gave significantly lower conversion rates of $46-70 \%$ after the same illumination time, presumably due to the poor transport and thus mixing of these materials within the reactor's tube. 
Table 8. Experimental details of selected photooxidations of 1,5-dihydroxynaphthalene (30).

\begin{tabular}{|c|c|c|c|c|c|}
\hline & Reaction 33 & Reaction 34 & Reaction 35 & Reaction 36 & Reaction 37 \\
\hline reactor & $\begin{array}{c}\text { horizontal } \\
\text { trough }\end{array}$ & $\begin{array}{l}\text { horizontal } \\
\text { trough }\end{array}$ & $\begin{array}{l}\text { horizontal } \\
\text { trough }\end{array}$ & $\begin{array}{l}\text { horizontal } \\
\text { trough }\end{array}$ & $\begin{array}{l}\text { vertical } \\
\text { trough }\end{array}$ \\
\hline CF & 15 suns & 15 suns & 15 suns & 15 suns & 18 suns \\
\hline reflector & holographic & holographic & aluminum & aluminum & aluminum \\
\hline diol 30 & $2.0 \mathrm{~g}$ & $1.0 \mathrm{~g}$ & $2.0 \mathrm{~g}$ & $2.0 \mathrm{~g}$ & $0.5 \mathrm{~g}$ \\
\hline solvent & $\begin{array}{c}200 \mathrm{~mL} \\
\left({ }^{\mathrm{i}} \mathrm{PrOH}\right)\end{array}$ & $\begin{array}{l}200 \mathrm{~mL} \\
\text { ('PrOH) }\end{array}$ & $\begin{array}{c}250 \mathrm{~mL} \\
\left({ }^{\mathrm{i}} \mathrm{PrOH}\right)\end{array}$ & $\begin{array}{c}250 \mathrm{~mL} \\
\text { (acetone) }\end{array}$ & $\begin{array}{c}100 \mathrm{~mL} \\
\text { ('PrOH) }\end{array}$ \\
\hline sensitizer & $0.1 \mathrm{~g}(\mathrm{RB})$ & $0.1 \mathrm{~g}(\mathrm{RB})$ & $0.1 \mathrm{~g}(\mathrm{RB})$ & $0.1 \mathrm{~g}(\mathrm{RB})$ & $0.05 \mathrm{~g}(\mathrm{RB})$ \\
\hline time & $\begin{array}{c}8 \mathrm{~h}^{1} \\
(2 \text { days })\end{array}$ & $\begin{array}{c}3 \mathrm{~h}^{1} \\
\text { (2 days) }\end{array}$ & $\begin{array}{c}4 \mathrm{~h}^{1} \\
\text { (1 day) }\end{array}$ & $\begin{array}{c}4 \mathrm{~h}^{1} \\
\text { (1 day) }\end{array}$ & $\begin{array}{l}2 / 3 \mathrm{~h}^{1} \\
\text { (1 day) }\end{array}$ \\
\hline conversion ${ }^{2}$ & $83 \%$ & $>95 \%$ & $93 \%$ & $99 \%$ & $>95 \%$ \\
\hline yield of $\mathbf{3 1}{ }^{3}$ & $54 \%$ & $79 \%$ & $75 \%$ & $79 \%$ & $71 \%$ \\
\hline
\end{tabular}

${ }^{1}$ Illumination time (over number of days). ${ }^{2}$ Conversion of 30 by GC. ${ }^{3}$ Isolated yields of 31.

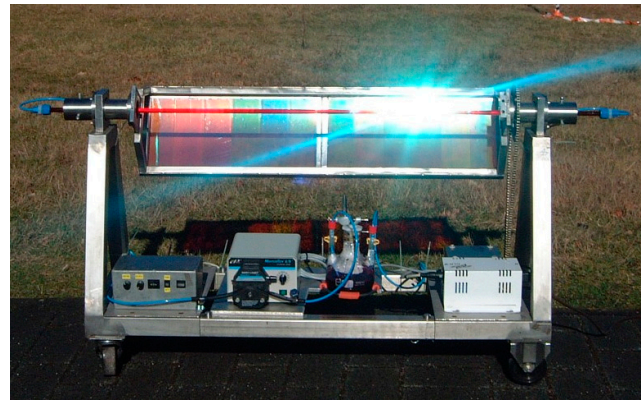

(a)

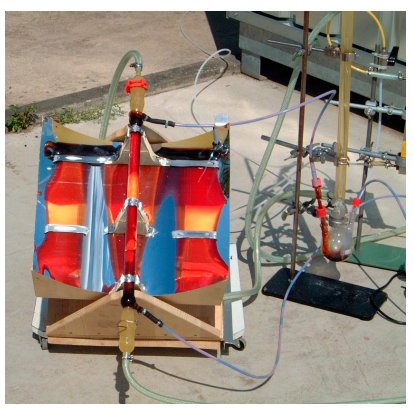

(b)

Figure 9. Laboratory-scale parabolic trough concentrators at the German Aerospace Center (DLR) in Cologne-Porz, Germany. (a) Horizontal trough reactor equipped with holographic mirrors (the reflected green light can be clearly seen), 2003.

(b) Vertical trough reactor based on a Liebig condenser, 2003 (taken from [115]).

Three additional solar photooxygenations involving diol 30 were furthermore conducted in a simple vertical parabolic trough reactor that used a Liebig condenser with a diameter of $2.4 \mathrm{~cm}$ as receiver tube (Figure 9b) [115]. The device used a bent polished aluminum sheet with an aperture of approx. $0.15 \mathrm{~m}^{2}(41 \times 36 \mathrm{~cm})$ and had a theoretical concentration factor of ca. 18 suns. The reaction mixture containing $30(0.5-1.0 \mathrm{~g})$ in either isopropanol or methanol $(100 \mathrm{~mL})$ was pumped through the outer mantle of the condenser, while cooling water was passed upwards through its central tube. After solar illuminations for effectively $2 / 3-4 \frac{1}{2} \mathrm{~h}$, conversion rates of 30 of $\geq 86 \%$ and isolated yields of juglone (31) of $46-71 \%$ were obtained. The highest conversion and isolated yield were again achieved using rose bengal and isopropanol (reaction 37).

\subsection{Miscellaneous Solar Photooxygenations and Photooxidations}

Sensitized photooxidations of E-cinnamic acid (E-32) and methyl acrylate (34) in a parabolic dish concentrator (Figure 3) have been described by Dincalb and Icli [116]. Aerated solutions of $E-\mathbf{3 2}$ or $\mathbf{3 4}$ in methanol and in the presence of sulfoamino perylenediimide 8c (SULFAPER; $\left.\mathrm{R}=-\left(\mathrm{CH}_{2}\right)_{12} \mathrm{NHSO}_{2} \mathrm{OH}\right)$ were exposed to concentrated sunlight (approximately 21 suns) for up to four hours and after successive reduction, the product mixtures were analyzed by GC-MS coupling. Illumination of E-32 for four hours (Scheme 13) showed incomplete conversion and furnished a complex reaction mixture with Z-cinnamic acid (Z-32) and the anhydride 33 as the main products in amounts of ca. $18 \%$ and $12 \%$, respectively. Methyl acrylate (34), carbonic acid (35), 2-phenylethanol (36) and benzaldehyde (37) were identified as minor products. Additional exposure in the absence of $\mathbf{8 c}$ and under deaerated or aerated conditions delivered somewhat different product mixtures and 2-hydroxyacetaldehyde (38) was furthermore detected. In all case examined, direct 
photoisomerization to the isomeric Z-cinnamic acid (Z-32) was found as the dominate reaction pathway. The formation of 33, 36 and 37 was explained via photoinduced electron transfer and the involvement of the super oxide anion radical $\left(\mathrm{O}_{2}{ }^{\bullet-}\right)$. The small scale and the rather complex outcome of this transformation limit its usefulness in organic synthesis.

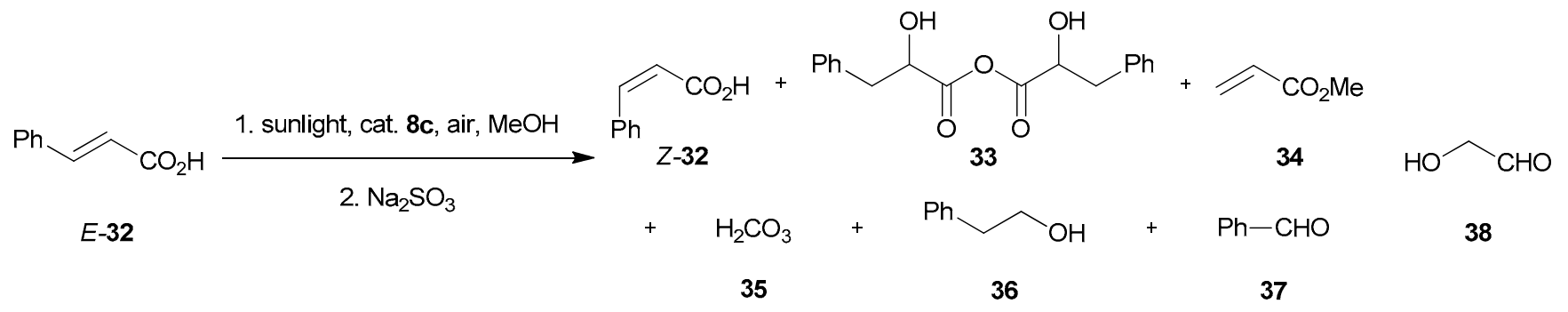

$2.5 \mathrm{mmol}$ of $E-32$ and catalytic amounts of $8 \mathrm{c}$ in bacic $\mathrm{MeOH}(25 \mathrm{~mL})$ at $\mathrm{pH} 11$

ca. $42 \%$ conversion of $E-32$ and Z-32 : $33: 34: 35: 36: 37$ in ca. $18: 12: 7: 4:<1:<1 \%$ (by GC/MS) after 4 hours at approx. 21 suns

Scheme 13. SULFAPER-sensitized photooxidations of $E$-cinnamic acid (E-32).

The SULFAPER-sensitized reaction of methyl acrylate (34) in basic methanol was much more selective (Scheme 14) [116]. Exposure to concentrated sunlight under aerated conditions for one hour furnished complete conversion of $\mathbf{3 4}$ and methyl 2-oxopropanoate (39) was obtained as the only product. Shorter illumination for $\frac{1}{4}$ hour under the same conditions also produced carbonic acid (35) in ca. 10\%, next to 39 and residual 34 in amounts of approximately $69 \%$ and $21 \%$, respectively. In the absence of the photosensitizer $8 c$, solar exposure for one hour resulted in a low conversion of just ca. $27 \%$ and gave carbonic acid (35) and 2-hydroxyacetaldehyde (38) as the only photoproducts in amounts of ca. $16 \%$ and $11 \%$. Under deareated conditions in the presence of SULFAPER, illuminations for $\frac{1}{4}$ or one hour yielded methyl 2-oxopropanoate (39) as the sole product in amounts of approx. $57 \%$ and $68 \%$ next to residual 34 . Electron transfer steps including the generation of the super oxide anion radical $\left(\mathrm{O}_{2}{ }^{\bullet-}\right)$ were postulated to explain the formation of 39 . Despite the selective nature of this particular transformation, the rather demanding technical requirements and the small reaction scale hinder a wider application.

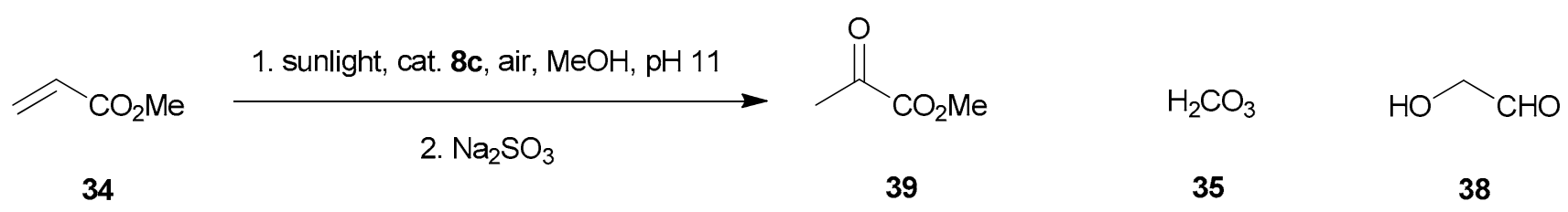

$2.5 \mathrm{mmol}$ of 34 and catalytic amounts of $8 \mathrm{c}$ in bacic $\mathrm{MeOH}(25 \mathrm{~mL})$ at $\mathrm{pH} 11$ complete conversion of $\mathbf{3 4}$ and quantitative yield of $\mathbf{3 9}$ (by GC/MS) after 1 hour at approx. 21 suns

Scheme 14. SULFAPER-sensitized photooxidations of methyl acrylate (34).

The solar photooxygenation of natural rosin or collophany, which is obtained from pine trees, has been investigated by Icli [117]. A solution of rosin in methanol containing methylene blue was exposed to concentrated sunlight in a Bomin Solar fixed focus concentrator capable of concentration factors of up to 2000 suns. A circulating reactor was positioned in the focal point (1-2 cm in diameter) of the solar dish. The reactor consisted of a double-jacked Pyrex tubing of $30 \mathrm{~cm}$ length with an outer diameter of $5.5 \mathrm{~cm}$ and an inner diameter of $4 \mathrm{~cm}$. This reaction tube was connected to a $2 \mathrm{~L}$ reservoir flask, which was cooled in an ice bath during operation. The reaction mixture was purged with oxygen in the reservoir and then circulated through the inner reaction tubing at $500 \mathrm{~mL} / \mathrm{min}$, while colling water was passed through the outer mantle. After six hours of circulation with occasional refeeding of methylene blue, the reaction product was treated with sodium metabisulfite $\left(\mathrm{Na}_{2} \mathrm{~S}_{2} \mathrm{O}_{5}\right)$, acidified to $\mathrm{pH} 4-5$ and the precipitated oxygenated rosin col- 
lected and analyzed. NMR and IR analyses revealed the presence of photooxygenated products with potentially enhanced emulsifier properties. As rosin consists mainly of abietic acid (39), its photooxygenation-reduction sequence to the oxygenated products 40-42 is exemplarily shown in Scheme 15. The author also suggested a potential industrial production of photooxygenated rosin from agricultural leftover stocks using four parabolic trough collectors with a moderate concentration factor of 50-100 suns and an aperture of $10 \mathrm{~m}^{2}$ each connected in series. In favorable regions with high levels of solar radiation, the plant was estimated to convert $100 \mathrm{~kg}$ of rosin in $300 \mathrm{~L}$ of methanol in three hours in summer, four to five hours in spring and six to eight hours in winter, respectively.
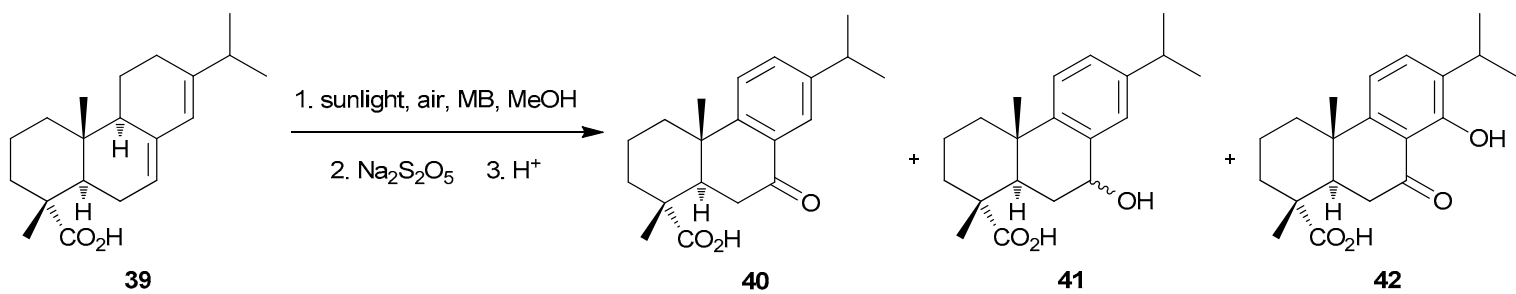

$500 \mathrm{~g}$ rosin and $150 \mathrm{mg}$ of $\mathrm{MB}$ (several $50 \mathrm{mg}$ refeeds) in $1.5 \mathrm{~L}$ oxygen-saturated $\mathrm{MeOH}$ complete oxygenation after 6 hours at $<2000$ suns

Scheme 15. Photooxygenation and thermal reduction of abietic acid (39), the major component in rosin, to its oxygenated products $40-42$.

Sensitized dehydrogenation reactions of natural pine rosin and abietic acid (39) were furthermore studied by Icli and co-workers in concentrated sunlight (Scheme 16) [118]. The authors utilized a non-specified solar dish concentrator with a diameter of $1 \mathrm{~m}$ and a cooled tube-shaped reactor placed in its focal point. Solutions containing rosin or 39, benzophenone $\left(\mathrm{Ph}_{2} \mathrm{CO}\right)$ and copper acetate $\left(\mathrm{Cu}(\mathrm{OAc})_{2} ;\left(\mathrm{CH}_{3} \mathrm{CO}_{2}\right)_{2} \mathrm{Cu}\right)$ in benzene were exposed to sunlight under nitrogen for up to three hours. Each experimental run was stopped eight times for aeration/degassing to regenerate cupric $\left(\mathrm{Cu}^{2+}\right)$ ions. Following this approach, abietic acid (39) was quantitatively converted to dehydroabietic acid (43). The authors concluded that the selective solar dehydrogenation to $\mathbf{4 3}$ may have commercial potential, although the reaction scale and hazardous solvent necessitate further optimization studies.<smiles>CC(C)C1=CC2=CC[C@H]3[C@](C)(C(=O)O)CCC[C@]3(C)[C@H]2CC1</smiles>

39

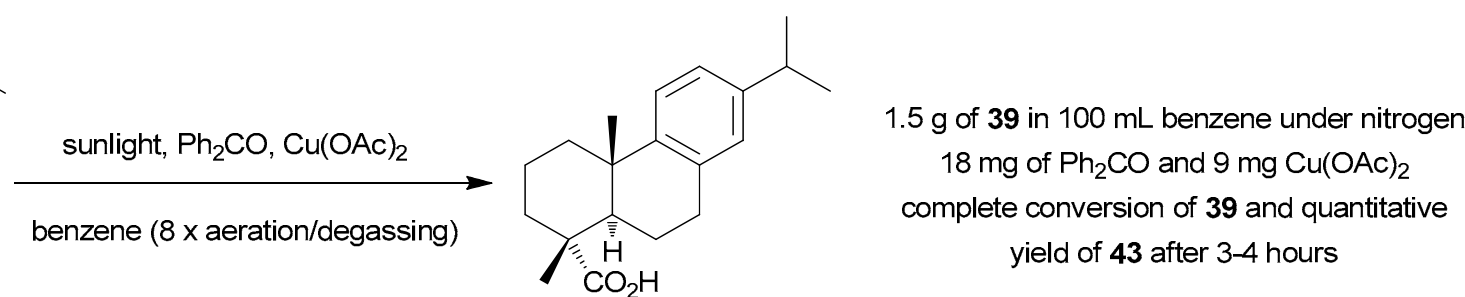

43

Scheme 16. Photodehydrogenation of abietic acid (39) to dehydroabietic acid (43).

The benzophenone-sensitized photodehydrogenation of acenaphthene (44) in the presence of cupric pivalate $\left(\mathrm{CuPiv}_{2}\right)$ was only observed in concentrated sunlight [85]. Using a fix focus solar dish reactor with a sunlight concentration factor below 15 suns (Figure 3), a degassed solution of 44 , benzophenone and $\mathrm{CuPiv}_{2}$ in carbon tetrachloride was illuminated for $30 \mathrm{~h}$ over a seven-day period with several aeration/degassing cycles. Subsequent GCMS analysis revealed the clean formation of acenaphthenone (45) in $95 \%$, next to $5 \%$ of unreacted 44 (Scheme 17). Continuous solar exposure under deaerated conditions for $7 \frac{1}{2} \mathrm{~h}$ with a concentration factor of under 110 suns resulted in a low conversion of just $3 \%$ with acetnaphthylene (46) detected by GC-MS in an amount of $<1 \%$. Prolonged illuminations for up to $20 \mathrm{~h}$ under the same conditions somewhat increased conversion rates to $11 \%$, 
but with only ca. $2 \%$ of $\mathbf{4 6}$ formed. The latter experiments unambiguously showed the importance of molecular oxygen $\left({ }^{3} \mathrm{O}_{2}\right)$ for catalyst regeneration.

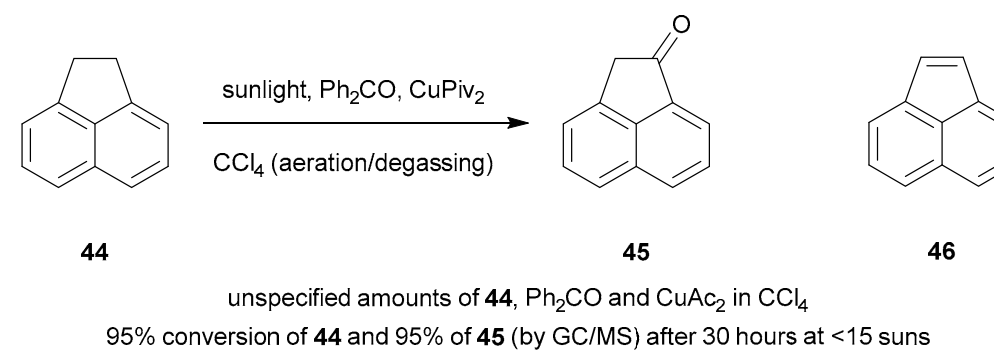

Scheme 17. Photodehydrogenation of acenaphthene (44) to acenaphthenone (45).

Icli and co-workers also investigated the naphthalene diimide-sensitized photooxidation of anthracene to its corresponding endoperoxide in the HTC reactor under 10.2 suns (Figure 3) [119]. However, no further experimental details were provided by the authors.

\section{Limitations, Challenges and Opportunities}

Although photooxygenations have been successfully realized 'outdoors' in natural sunlight on the demonstration to technical scales, many reported processes suffer from experimental or technical drawbacks. For example, very few solar manufacturing studies, notably rose oxide (15) [59], (-)-trans-4-hydroxy- $\beta$-thujene (23a) [102] and juglone (31) $[91,114,115]$, have truly isolated the oxygenated target products of interest. Most investigations obtained crude products instead and determined compositions and 'yields' simply by NMR, GC or GC-MS analyses. A further conversion of a crude reaction mixture followed by isolation of the desired product (hexyloxyfuranone 28; $\mathrm{R}=\mathrm{Hex}$ ) has nevertheless been described [111]. Some processes generated complex mixtures, hence requiring time and resource demanding separation and purification steps. Several protocols also involved hazardous and flammable solvents from the corresponding 'indoor' (laboratory) procedure, which need major risk control measures. Other studies utilized highly sunlight-concentrating facilities such as parabolic dish systems or solar furnaces that place the reaction chamber within their focal points. Next to the high installation costs, these concentrators generate large amounts of heat and thus demand sophisticated and reliable cooling systems for effective heat management. Due to the limited capacity of the actual reaction chambers, these systems are also difficult to scale to industrially relevant productivities.

Preparative solar chemistry has seen a surge between 1990 and 2005, largely driven by dedicated research programs involving the PSA in Spain and the DLR in Germany [120]. Despite the realization of a variety of attractive solar transformations during this period, the developed technologies and processes were not implemented by the chemical industry. A major hurdle for adaptation may have been the high initial investment costs, especially for more advanced sunlight concentrator systems, and the need for 'operation security' independent of location or weather. In contrast to the more complex trough or dish reactors, low sunlight-concentrating systems such as the CPC reactor are easy to manufacture and maintain and can furthermore utilize direct and diffuse radiation. This makes this device advantageous for the construction of solar chemical plants, as already successfully demonstrated for large-scale wastewater treatment processes [57,58]. The initial construction costs for these facilities may be offset by annual savings on energy, cooling water and replacement lamps [95]. At present, the transfer of existing photochemical processes from the fragrance and flavor industry to solar operations appears economically and technically viable. These (and other) fine and specialty products are manufactured on scales below 1000 tons/year and thus do not necessarily require continuous, year-round operation [121-123].

Naturally, the location of any future synthetic-organic solar industry will demand favorable sunlight conditions, but also existing infrastructure and access to target markets. 
For larger chemical markets or less favorable locations, however, tandem solar lamp-driven processes can overcome the reliance on the day-night cycle and hence guarantee a continuous production of target materials. Under inadequate sunlight conditions or at night, energy efficient light sources such as LEDs or OLEDs can drive or support the photochemical process $[13,124,125]$. Prototype solar lamp-driven devices have indeed already been developed and applied for water treatment applications $[126,127]$. Solar photochemistry also offers economic benefits for decentralized manufacturing, for example small-scale conversions of local biomass in the (tropical) essential oil industry or in developing countries $[128,129]$. In isolated and remote locations, photovoltaic $(\mathrm{PV})$ panels can provide power for electrical components, as again successfully demonstrated for water treatment applications [130,131].

\section{Conclusions and Outlook}

Photooxygenations are ideal candidates for preparative solar applications with significant future synthesis potential $[132,133]$. Industrially relevant and new processes have been realized using a variety of solar reactor systems, clearly demonstrating the capability of this methodology. Current or future technologies and processes developed can be further adopted and transferred to other photochemical or even thermal applications [39-47,134]. Visible-light photoredox catalysis, for example, has seen remarkable growth over the last decade [135-137], but no large-scale solar processes have been reported yet [138]. Likewise, new solar chemical reactor concepts have been recently developed, including continuous-flow trough and luminescent solar concentrators [139-141]. These chemical and technological advances have complemented past and existing activities in green photochemistry [142-148]. It is hoped that the future of solar photochemistry in general as a sustainable synthesis tool will be bright [149].

Author Contributions: J.S.W. wrote the original draft manuscript; M.J.R. provided corrections to the final version; M.O. revised the manuscript and secured the funding. All authors have read and agreed to the published version of the manuscript.

Funding: This research was funded by the Australian Research Council (ARC; grant number DP130100794) and the Queensland Department of Employment, Economic Development \& Innovation (DEEDI; Proof of Concept Grant 2012).

Acknowledgments: The authors thank emeritus Prof Jochen Mattay, Christian Jung, Christian Sattler, Jürgen Ortner and Peter Esser for their ongoing support over the years. The authors also thank emeritus Prof Siddik Icli for information on the parabolic dish solar concentrator.

Conflicts of Interest: The authors declare no conflict of interest.

\section{References}

1. Bonfield, H.E.; Knauber, T.; Lévesque, F.; Moschetta, E.G.; Susanne, F.; Edwards, L.J. Photons as a 21st century reagent. Nat. Commun. 2020, 11, 1-4. [CrossRef] [PubMed]

2. Griesbeck, A.G. The Future of Photochemistry: Just Bright. ChemPhotoChem 2018, 3, 8-9. [CrossRef]

3. Pagliaro, M. Making APIs and fine chemicals with light. Chim. Oggi-Chem. Today 2017, 35, 84-85.

4. Bach, T. More Chemistry with light! More light in chemistry! Angew. Chem. Int. Ed. 2015, 54, 11294-11295. [CrossRef]

5. Balzani, V.; Bergamini, G.; Ceroni, P. Photochemistry and photocatalysis. Rend. Lincei 2017, 28, 125-142. [CrossRef]

6. Kärkäs, M.D.; Porco, J.A., Jr.; Stephenson, C.R.J. Photochemical approaches to complex chemotypes: Applications in natural product synthesis. Chem. Rev. 2016, 116, 9683-9747. [CrossRef]

7. Oelgemöller, M.; Hoffmann, N. Studies in organic and physical photochemistry-An interdisciplinary approach. Org. Biomol. Chem. 2016, 14, 7392-7442. [CrossRef] [PubMed]

8. Hoffmann, N. Photochemical Reactions as Key Steps in Organic Synthesis. Chem. Rev. 2008, 108, 1052-1103. [CrossRef]

9. Rehm, T.H. Reactor Technology Concepts for Flow Photochemistry. ChemPhotoChem 2019, 4, 235-254. [CrossRef]

10. Di Filippo, M.; Bracken, C.; Baumann, M. Continuous Flow Photochemistry for the Preparation of Bioactive Molecules. Molecules 2020, 25, 356. [CrossRef]

11. Politano, F.; Oksdath-Mansilla, G. Light on the Horizon: Current Research and Future Perspectives in Flow Photochemistry. Org. Process. Res. Dev. 2018, 22, 1045-1062. [CrossRef] 
12. Oelgemöller, M.; Hoffmann, N.; Shvydkiv, O.; Oelgemoeller, M. From 'Lab \& Light on a Chip' to Parallel Microflow Photochemistry. Aust. J. Chem. 2014, 67, 337-342. [CrossRef]

13. Sender, M.; Ziegenbalg, D. Light Sources for Photochemical Processes-Estimation of Technological Potentials. Chem. Ing. Tech. 2017, 89, 1159-1173. [CrossRef]

14. Braun, A.M.; Oller do Nascimento, C.A. Angewandte (präparative) Photochemie. Nachr. Chem. Tech. Lab. 1991, 39, 515-526.

15. Braun, A.; Peschl, G.H.; Oliveros, E. Industrial photochemistry. In CRC Handbook of Organic Photochemistry and Photobiology, 3rd ed.; Griesbeck, A., Oelgemöller, M., Ghetti, F., Eds.; CRC Press: Boca Raton, FL, USA, 2012; Volume 1, Chapter 1; pp. 1-19.

16. Michelin, C.; Lefebvre, C.; Hoffmann, N. Les réactions photochimiques à l'échelle industrielle. L'Act. Chim. 2019, 436, 19-27.

17. Pfoertner, K.-H.; Oppenländer, T. Photochemistry. In Ullmann's Encyclopedia of Industrial Chemistry; Wiley-VCH: Weinheim, Germany, 2012; pp. 1-45.

18. Braun, A.M.; Jakob, L.; Oliveros, E.; Nascimento, C.A.O.D. Up-Scaling Photochemical Reactions. Adv. Photochem. 2007, 18, 235-313. [CrossRef]

19. Fischer, M. Industrial Applications of Photochemical Syntheses. Angew. Chem. Int. Ed. 1978, 17, 16-26. [CrossRef]

20. Mattay, J. Von der Laborsynthese zur Solarchemie. Chem. unsere Zeit 2002, 36, 98-106. [CrossRef]

21. Wilkins, F.W.; Blake, D.M. Use solar energy to drive chemical processes. Chem. Eng. Prog. 1994, 90, 41-49.

22. Funken, K.-H. Solare Photoreaktionen für die chemische Technik. Nachr. Chem. Tech. Lab. 1992, 40, 793-800. [CrossRef]

23. Mathur, V.; Wong, E. Production of fuels and chemicals using solar photothermochemistry. Energy 1987, 12, 311-318. [CrossRef]

24. Albini, A.; Dichiarante, V. The 'belle 'epoque' of photochemistry. Photochem. Photobiol. Sci. 2009, 8, 248-254. [CrossRef]

25. Roth, H.D. Twentieth century developments in photochemistry. Brief historical sketches. Pure Appl. Chem. 2001, 73, 395-403. [CrossRef]

26. Roth, H.D. The Beginnings of Organic Photochemistry. Angew. Chem. Int. Ed. 1989, 28, 1193-1207. [CrossRef]

27. Ciamician, G. The photochemistry of the future. Science 1912, 36, 385-394. [CrossRef]

28. Protti, S.; Fagnoni, M. The sunny side of chemistry: Green synthesis by solar light. Photochem. Photobiol. Sci. 2009, 8, 1499-1516. [CrossRef]

29. Ravelli, D.; Protti, S.; Fagnoni, M. Application of Visible and Solar Light in Organic Synthesis. Lect. Notes Chem. 2016, 92, 281-342. [CrossRef]

30. Fuqiang, W.; Ziming, C.; Jianyu, T.; Yuan, Y.; Yong, S.; Linhua, L. Progress in concentrated solar power technology with parabolic trough collector system: A comprehensive review. Renew. Sustain. Energy Rev. 2017, 79, 1314-1328. [CrossRef]

31. Weinstein, L.A.; Loomis, J.; Bhatia, B.S.; Bierman, D.M.; Wang, E.N.; Chen, G. Concentrating Solar Power. Chem. Rev. 2015, 115, 12797-12838. [CrossRef]

32. Fernández-García, A.; Zarza, E.; Valenzuela, L.; Pérez, M. Parabolic-trough solar collectors and their applications. Renew. Sustain. Energy Rev. 2010, 14, 1695-1721. [CrossRef]

33. Roeb, M.; Neises, M.; Monnerie, N.; Sattler, C.; Pitz-Paal, R. Technologies and trends in solar power and fuels. Energy Environ. Sci. 2011, 4, 2503-2511. [CrossRef]

34. Funken, K.-H.; Ortner, J. Technologies for the Solar Photochemical and Photocatalytic Manufacture of Specialities and Commodities: A Review. Z. Phys. Chem. 1999, 213, 99-105. [CrossRef]

35. Fendrich, M.A.; Quaranta, A.; Orlandi, M.; Bettonte, M.; Miotello, A. Solar Concentration for Wastewaters Remediation: A Review of Materials and Technologies. Appl. Sci. 2018, 9, 118. [CrossRef]

36. Malato, S.; Maldonado, M.I.; Fernández-Ibáñez, P.; Oller, I.; Polo, I.; Sánchez-Moreno, R. Decontamination and disinfection of water by solar photocatalysis: The pilot plants of the Plataforma Solar de Almeria. Mater. Sci. Semicond. Process. 2016, 42, 15-23. [CrossRef]

37. Tanveer, M.; Guyer, G.T. Solar assisted photo degradation of wastewater by compound parabolic collectors: Review of design and operational parameters. Renew. Sustain. Energy Rev. 2013, 24, 534-543. [CrossRef]

38. Bahnemann, D. Photocatalytic water treatment: Solar energy applications. Sol. Energy 2004, 77, 445-459. [CrossRef]

39. Oelgemöller, M. Solar Photochemical Synthesis: From the Beginnings of Organic Photochemistry to the Solar Manufacturing of Commodity Chemicals. Chem. Rev. 2016, 116, 9664-9682. [CrossRef]

40. Spasiano, D.; Marotta, R.; Malato, S.; Fernandez-Ibañez, P. Solar photocatalysis: Materials, reactors, some commercial, and pre-industrialized applications. A comprehensive approach. Appl. Cat. B Environ. 2015, 170, 90-123. [CrossRef]

41. Oelgemöller, M.; Jung, C.; Mattay, J.; Oelgemoeller, M. Green photochemistry: Production of fine chemicals with sunlight. Pure Appl. Chem. 2007, 79, 1939-1947. [CrossRef]

42. Esser, P.; Pohlmann, B.; Scharf, H.-D. The Photochemical Synthesis of Fine Chemicals with Sunlight. Angew. Chem. Int. Ed. 1994, 33, 2009-2023. [CrossRef]

43. Mumtaz, S.; Sattler, C.; Oelgemöller, M. Solar photochemical manufacturing of fine chemicals—historical background, modern solar technologies, recent applications and future challenges. In Chemical Processes for a Sustainable Future; Letcher, T.M., Scott, J.L., Patterson, D., Eds.; Royal Society of Chemistry: Cambridge, UK, 2015; Chapter 7; pp. 158-191.

44. Coyle, E.E.; Oelgemöller, M. Solar photochemistry from the beginnings of organic photochemistry to the solar production of chem-icals. In CRC Handbook of Organic Photochemistry and Photobiology, 3rd ed.; Griesbeck, A., Oelgemöller, M., Ghetti, F., Eds.; CRC Press: Boca Raton, FL, USA, 2012; Volume 1, Chapter 10; pp. 237-247. 
45. Oelgemöller, M.; Jung, C.; Ortner, J.; Mattay, J.; Schiel, C.; Zimmermann, E. Green photochemistry with moderately concentrated sunlight. Spectrum 2005, 18, 28-33.

46. Oelgemöller, M.; Mattay, J.; Jung, C.; Schiel, C.; Ortner, C.; Zimmermann, E. Back to the roofs-the solarchemical production of fine chemicals with sunlight. In Proceedings of the International Solar Energy Conference, ISEC 2004 Conference, Portland, OR, USA, 11-14 July 2004; American Society of Mechanical Engineers (ASME): New York, NY, USA, 2004; pp. 523-531.

47. Pohlmann, B.; Scharf, H.-D.; Jarolimek, U.; Mauermann, P. Photochemical production of fine chemicals with concentrated sunlight. Sol. Energy 1997, 61, 159-168. [CrossRef]

48. Fu, Q. Radiation (solar). In Encyclopedia of Atmospheric Sciences; Holton, J., Ed.; Academic Press: Amsterdam, The Netherlands, 2003; pp. 1859-1863.

49. Iqbal, M. An Introduction to Solar Radiation; Academic Press: New York, NY, USA, 1983.

50. Pibiri, I.B.; Piccionello, S.; Palumbo, A.; Pace, A. Photochemically produced singlet oxygen: Applications and perspectives. ChemPhotoChem 2018, 2, 535-547. [CrossRef]

51. Ghogare, A.A.; Greer, A. Using Singlet Oxygen to Synthesize Natural Products and Drugs. Chem. Rev. 2016, 116, 9994-10034. [CrossRef]

52. DeRosa, M.C.; Crutchley, R.J. Photosensitized singlet oxygen and its applications. Coord. Chem. Rev. 2002, 233-234, 351-371. [CrossRef]

53. Turconi, J.; Griolet, F.; Guevel, R.; Oddon, G.; Villa, R.; Geatti, A.; Hvala, M.; Rossen, K.; Göller, R.; Burgard, A. Semisynthetic Artemisinin, the Chemical Path to Industrial Production. Org. Process. Res. Dev. 2014, 18, 417-422. [CrossRef]

54. Gollnick, K. Photooxygenation and its application in industry. Chim. Ind. 1982, 64, 156-166. [CrossRef]

55. Rojahn, W.; Warnecke, H.-U. Die Photosensibilisierte Sauerstoffübertragung —eine Methode zur Herstellung hochwertiger Riech-stoffe. Dragoc. Rep. 1980, 27, 159-164.

56. Demuth, M. Chemie mit Sonnenlicht—auch bei Bewölkung. In Innovationspreis Ruhrgebiet; Kommunalverband Ruhrgebiet: Essen, Germany, 2000; pp. 91-94.

57. Blanco, J.; Malato, S.; Fernández, P.; Vidal, A.; Morales, A.; Trincado, P.; Oliveira, J.; Minero, C.; Musci, M.; Casalle, C.; et al. Compound parabolic concentrator technology development to commercial solar detoxification applications. Sol. Energy 1999, 67, 317-330. [CrossRef]

58. Ajona, J.; Vidal, A. The use of CPC collectors for detoxification of contaminated water: Design, construction and preliminary results. Sol. Energy 2000, 68, 109-120. [CrossRef]

59. Jung, C.; Funken, K.-H.; Ortner, J. Prophis: Parabolic trough-facility for organic photochemical syntheses in sunlight. Photochem. Photobiol. Sci. 2005, 4, 409-411. [CrossRef]

60. Funken, K.-H. Solar chemistry using concentrating solar facilities. In Proceedings of the Sixth International Summer School Solar Energy 2000, Klagenfurt, Austria, 24 July-4 August 2000; Faninger, G., Bucher, W., Wolfer, U., Eds.; Interuniversitäres Institut für interdisziplinäre Forschung und Fortbildung (IFF), Universität Klagenfurt: Klagenfurt, Austria, 2001; pp. 118-137.

61. Neumann, A.; Groer, U. Experimenting with concentrated sunlight using the DLR solar furnace. Sol. Energy 1996, 58, 181-190. [CrossRef]

62. Fields, C.L.; Pitts, J.R.; Hale, M.J.; Bingham, C.; Lewandowski, A.; King, D.E. Formation of fullerenes in highly concentrated solar flux. J. Phys. Chem. 1993, 97, 8701-8702. [CrossRef]

63. Flamant, G.; Luxembourg, D.; Robert, J.; Laplaze, D. Optimizing fullerene synthesis in a $50 \mathrm{~kW}$ solar reactor. Sol. Energy 2004, 77, 73-80. [CrossRef]

64. Foote, C.S. Definition of type I and type II photosensitized oxidation. Photochem. Photobiol. 1991, 54, 659. [CrossRef]

65. Schmidt, R. Photosensitized Generation of Singlet Oxygen. Photochem. Photobiol. 2007, 82, 1161-1177. [CrossRef]

66. Osterberg, P.M.; Niemeier, J.K.; Welch, C.J.; Hawkins, J.M.; Martinelli, J.R.; Johnson, T.E.; Root, T.W.; Stahl, S.S. Experimental lim-iting oxygen concentrations for nine organic solvents at temperatures and pressures relevant to aerobic oxidations in the pharma-ceutical industry. Org. Process. Res. Dev. 2015, 19, 1537-1543. [CrossRef] [PubMed]

67. Montalti, M.; Credi, A.; Prodi, L.; Gandolfi, M.T. Handbook of Photochemistry, 3rd ed.; CRC Press: Boca Raton, FL, USA, 2006; pp. 542-548.

68. Clarke, C.J.; Tu, W.-C.; Levers, O.; Bröhl, A.; Hallett, J.P. Green and Sustainable Solvents in Chemical Processes. Chem. Rev. 2018, 118, 747-800. [CrossRef]

69. Fresnadillo, D.G.; Lacombe, S. Reference photosensitizers for the production of singlet oxygen. In Singlet Oxygen: Applications in Biosciences and Nanosciences; Nonell, S., Flors, C., Eds.; The Royal Society of Chemistry: Cambridge, UK, 2016; Volume 1, Chapter 6; pp. 105-143.

70. Marin, M.L.; Santos-Juanes, L.; Arques, A.; Amat, A.M.; Miranda, M.A. Organic photocatalysts for the oxidation of pollutants and model compounds. Chem. Rev. 2012, 112, 1710-1750. [CrossRef]

71. Lacombe, S.; Pigot, T. Materials for selective photo-oxygenation vs. photocatalysis: Preparation, properties and applications in en-vironmental and health fields. Catal. Sci. Technol. 2016, 6, 1571-1592. [CrossRef]

72. Wahlen, J.; De Vos, D.E.; Jacobs, P.A.; Alsters, P.L. Solid Materials as Sources for Synthetically Useful Singlet Oxygen. Adv. Synth. Catal. 2004, 346, 152-164. [CrossRef] 
73. Malakar, P.; Deb, A.R.; Goodine, T.; Robertson, M.J.; Oelgemöller, M. Continuous-flow photooxygenations: an advantageous and sustainable oxidation methodology with a bright future. In Catalytic Aerobic Oxidations_Catalysis Series; Mejía, E., Ed.; Royal Society of Chemistry: Cambridge, UK, 2020; Chapter 7, pp. 181-251. [CrossRef]

74. Nardello-Rataj, V.; Alsters, P.L.; Aubry, J.-M. Industrial Prospects for the Chemical and Photochemical Singlet Oxygenation of Organic Compounds. Liq. Phase Aerob. Oxid. Catal. Ind. Appl. Acad. Persp. 2016, 22, 369-395. [CrossRef]

75. Alberti, M.N.; Orfanopoulos, M. Unravelling the mechanism of the singlet oxygen ene reaction: Recent computational and experi-mental approaches. Chem. Eur. J. 2010, 16, 9414-9421. [CrossRef] [PubMed]

76. Bayer, P.; Pérez-Ruiz, R.; Von Wangelin, A.J. Stereoselective Photooxidations by the Schenck Ene Reaction. ChemPhotoChem 2018, 2, 559-570. [CrossRef]

77. Khayyat, S.A.; Roselin, L.S. Recent progress in photochemical reaction on main components of some essential oils. J. Saudi Chem. Soc. 2018, 22, 855-875. [CrossRef]

78. Goodine, T.; Oelgemöller, M. Corymbia citriodora: A Valuable Resource from Australian Flora for the Production of Fragrances, Repellents, and Bioactive Compounds. ChemBioEng Rev. 2020, 7, 170-192. [CrossRef]

79. Schenck, O.; Ziegler, K. Die Synthese des Ascaridols. Naturwissenschaften 1944, 32, 157. [CrossRef]

80. Schenck, G.O. Autoxydation von Furan und anderen Dienen (Die Synthese des Ascaridols). Ang. Chem. 1944, 57, 101-102. [CrossRef]

81. Schenck, G.; Schulze-Buschoff, H. Synthetisches Askaridol, eine neue Möglichkeit der Spulwurmbehandlung. DMW-Dtsch Med. Wochenschr. 1948, 73, 341-344. [CrossRef] [PubMed]

82. Karapire, C.; Kolancilar, H.; Oyman, Ü.; Icli, S. Fluorescence emission and photooxidation studies with 5,6- and 6,7benzocoumarins and a 5,6-benzochromone under direct and concentrated sun light. J. Photochem. Photobiol. Chem. 2002, 153, 173-184. [CrossRef]

83. Dindar, B.; Içli, S. Unusual photoreactivity of zinc oxide irradiated by concentrated sunlight. J. Photochem. Photobiol. Chem. 2001, 140, 263-268. [CrossRef]

84. Karapire, C.; Kuś, M.; Turkmen, G.; Trevithick-Sutton, C.; Foote, C.; Icli, S. Photooxidation studies with perylenediimides in solution, PVC and sol-gel thin films under concentrated sun light. Sol. Energy 2005, 78, 5-17. [CrossRef]

85. Avcibasi, N.; Icli, S.; Gilbert, A. Photochemical reactions of $\alpha$-terpinene and acenaphthene under concentrated sunlight. Turk. J. Chem. 2003, 27, 1-7.

86. Ohloff, G.; Klein, E.; Schenck, G.O. Darstellung von “Rosenoxyden” und anderen Hydropyran-Derivaten über Photohydroperoxyde. Angew. Chem. 1961, 73, 578. [CrossRef]

87. Bicas, J.L.; Dionísio, A.P.; Pastore, G.M. Bio-oxidation of Terpenes: An Approach for the Flavor Industry. Chem. Rev. 2009, 109, 4518-4531. [CrossRef]

88. Pickenhagen, W.; Schatkowski, D. Verfahren zur Herstellung von Rosenoxid. DE19645922A1, 14 February 2002.

89. Demuth, M.; Ritter, A. Photochemical and Thermochemical Solar Syntheses Using Flat-Bed Solar Collectors/Solar Reactors. WO99/54042A1, 28 October 1999.

90. Ritterskamp, P.; Hülsdünker, A.; Heimann, F.; Goeller, F.; Uzun, D.; Ritter, A.; Demuth, M.; Kleinwächter, J.; Ortner, J.; Funken, K.-H.; et al. Synthesis of biologically active compounds with sunlight and technological developments. In Solare Chemie und Solare Materialforschung; AG-Solar NRW: Jülich, Germany, 2002; Chapter 2.2.1; pp. 1-6. ISBN 3893363068.

91. Oelgemöller, M.; Jung, C.; Ortner, J.; Mattay, J.; Zimmermann, E.; Oelgemoeller, M. Green photochemistry: Solar photooxygenations with medium concentrated sunlight. Green Chem. 2004, 7, 35-38. [CrossRef]

92. Ortner, J.; Faust, D.; Funken, K.-H.; Lindner, T.; Schulat, J.; Stojanoff, C.G.; Fröning, P. New developments using holographic concentration in solar photochemical reactors. J. Phys. Colloq. 1999, 9, Pr3-379-Pr3-383. [CrossRef]

93. Stojanoff, C.G.; Schulat, J.; Fröning, P. Development and fabrication of holographic concentrators for solar chemistry. In Solare Chemie und Solare Materialforschung; AG-Solar NRW: Jülich, Germany, 2002; Chapter 6.4; pp. 1-10. ISBN 3893363068.

94. Funken, K.-H.; Pohlmann, B.; Ortner, J.; Faust, D. Verfahren zur Oxidation ungesättigter Kohlenwasserstoffe. DE19923071A1, 21 August 2003.

95. Monniere, N.; Ortner, J. Economic evaluation of the industrial photosynthesis of rose oxide via lamp or solar operated photooxidation of citronellol. J. Sol. Energy Eng. 2001, 123, 171-174. [CrossRef]

96. Dincalp, H.; Icli, S. Photosynthesis of rose oxide by concentrated sunlight in the absence of singlet oxygen. J. Photochem. Photobiol. Chem. 2001, 141, 147-151. [CrossRef]

97. Schenck, G.O.; Eggert, H.; Denk, W. Über die Bildung von Hydroperoxyden bei photosensibilisierten Reaktionen von $\mathrm{O}_{2}$ mit ge-eigneten Akzeptoren, insbesondere mit $\alpha$ - und $\beta$-Pinen. Liebigs Ann. Chem. 1953, 584, 177-198. [CrossRef]

98. Bhatia, S.; McGinty, D.; Letizia, C.; Api, A. Fragrance material review on myrtenol. Food Chem. Toxicol. 2008, 46, S237-S240. [CrossRef] [PubMed]

99. Mihelich, E.D.; Eickhoff, D.J. A one-pot conversion of olefins to. alpha.,. beta.-unsaturated carbonyl compounds. An easy synthesis of 2-cyclopentenone and related compounds. J. Org. Chem. 1983, 48, 4135-4137. [CrossRef]

100. Jung, C.; Ortner, J.; Jarolimek, U.; Mauermann, P.; Leyen, B. Advances in photochemical production of fine chemicals with con-centrated sunlight. In Solare Chemie und Solare Materialforschung; AG-Solar NRW: Jülich, Germany, 2002; Chapter 2.2.1; pp. 1-10. ISBN 3893363068.

101. Neckers, D.C. Rose Bengal. J. Photochem. Photobiol. Chem. 1989, 47, 1-29. [CrossRef] 
102. Esser, P. Die Anwendung von Sonnenlicht zur Photochemischen Producktion von Feinchemikalien. Ph.D. Thesis, RheinischWestfälische Technische Hochschule, Aachen, Germany, 1994.

103. Funken, K.-H.; Schneider, G.; Esser, E.P.; Scharf, H.-D.; Esser, P.; Wöhrle, I. The SOLARIS-experiment: Demonstration of solar-photochemical syntheses of fine chemicals. In Proceedings of the 6th International Symposium on Solar Thermal Concentrating Technologies, Mojacar, Spain, 28 September-2 October 1992; Centro de Investigaciones Energétical, Medioambientales y Tecnológias (CIEMAT): Madrid, Spain, 1992; Volume 2, pp. 1027-1037.

104. Klein, E.; Rojahn, W. Die photosensibilisierte $\mathrm{O}_{2}$-Übertragung auf (+)- $\alpha$-Thujen. Chem. Ber. 1965, 98, 3045-3049. [CrossRef]

105. Baeckström, P.; Koutek, B.; Šaman, D.; Vrkoč, J. A convenient synthesis of trans-sabinene hydrate from (-)-3-thujol via a highly selective ene reaction of singlet oxygen. Bioorg. Med. Chem. 1996, 4, 419-421. [CrossRef]

106. Scharf, H.-D.; Esser, P.; Kuhn, W.; Pelzer, R. Process for the Photooxidation of Terpene Olefins. US5620569A, 15 April 1997.

107. Schenck, G.O. Über die unsensibilisierte und photosensibilisierte Autoxydation von Furanen. Liebigs Ann. Chem. 1953, 584, 156-176. [CrossRef]

108. Schenck, G.O. Verfahren zur Herstellung von $\beta$-Acyl-acrylsäuren bzw. ihren Pseudoestern. DE875650C, 4 May 1953.

109. Bolz, G.; Wiersdorff, W.-W. Verfahren zur Herstellung von 2-Hydroxy-2,5-dihydrofuranon-(5). DE2111119A1, 14 September 1972.

110. Hoydonckx, H.E.; Van Rhijn, W.M.; De Vos, D.E.; A Jacobs, P. Furfural and Derivatives. In Ullmann's Encyclopedia of Industrial Chemistry; Wiley: Hoboken, NJ, USA, 2007; Volume 16, pp. 285-313.

111. Esser, P.; Pelzer, R.; Völkl, F. Verwendung substituierter Lactone als Riechstoffe. EP0761808A2, 19 May 1999.

112. Strugstad, M.P.; Despotovski, S. A summary of extraction, synthesis, properties, and potential uses of juglone: A literature review. J. Ecosyst. Manag. 2012,13,1-16.

113. Griffiths, J.; Chu, K.-Y.; Hawkins, C. Photosensitised oxidation of 1-naphthols. J. Chem. Soc. Chem. Commun. 1976, 676-677. [CrossRef]

114. Oelgemöller, M.; Healy, N.; De Oliveira, L.; Jung, C.; Mattay, J. Green photochemistry: Solar-chemical synthesis of Juglone with medium concentrated sunlight. Green Chem. 2006, 8, 831-834. [CrossRef]

115. Suchard, O.; Kane, R.; Roe, B.J.; Zimmermann, E.; Jung, C.; Waske, P.A.; Mattay, J.; Oelgemöller, M. Photooxygenations of 1-naphthols: An environmentally friendly access to 1,4-naphthoquinones. Tetrahedron 2006, 62, 1467-1473. [CrossRef]

116. Dincalp, H.; Icli, S. Photoinduced electron transfer-catalyzed processes of sulfoamine perylene diimide under concentrated sun light. Sol. Energy 2006, 80, 332-346. [CrossRef]

117. Icli, S. Production of oxygenated rosin emulsifier by a solar photoorganic chemical method. For. Chem. Rev. 1999, 102, 7-9.

118. Icli, S.; Bulut, A.; Gül, Y. Room temperature generation of dehydrogenated colophony: Solar chemical production. Turk. J. Chem. 1992, 16, 289-292.

119. Erten, S.; Alp, S.; Icli, S. Photooxidation quantum yield efficiencies of naphthalene diimides under concentrated sun light in com-parisons with perylene diimides. J. Photochem. Photobiol. Chem. 2005, 175, 214-220. [CrossRef]

120. Funken, K.-H.; Ortner, J.; Riffelmann, K.-J.; Sattler, C. New developments in solar photochemistry. J. Inf. Rec. 1998, $24,61-68$.

121. Tirronen, E.; Salmi, T. Process development in the fine chemical industry. Chem. Eng. J. 2003, 91, 103-114. [CrossRef]

122. Bruggink, A. Growth and efficiency in the (fine) chemical industry. Chim. Oggi 1998, 16, 44-47.

123. Pollak, P.; Vouillamoz, R. Fine Chemicals. In Ullmann's Encyclopedia of Industrial Chemistry; Wiley: Hoboken, NJ, USA, 2000; pp. 1-17.

124. Landgraf, S. Application of semiconductor light sources for investigations of photochemical reactions. Spectrochim. Acta Part A Mol. Biomol. Spectrosc. 2001, 57, 2029-2048. [CrossRef]

125. Kalyani, N.T.; Dhoble, S. Organic light emitting diodes: Energy saving lighting technology-A review. Renew. Sustain. Energy Rev. 2012, 16, 2696-2723. [CrossRef]

126. Monteiro, R.A.R.; Rodrigues-Silva, C.; Lopes, F.V.S.; Silva, A.M.T.; Boaventura, R.A.R.; Vilar, V.J.P. Evaluation of a solar/UV an-nular pilot scale reactor for $24 \mathrm{~h}$ continuous photocatalytic oxidation of n-decane. Chem. Eng. J. 2015, 280, 409-416. [CrossRef]

127. Navntoft, C.; Araujo, P.; Litter, M.I.; Apella, M.C.; Fernández, D.; Puchulu, M.E.; Hidalgo, M.D.V.; Blesa, M.A. Field Tests of the Solar Water Detoxification SOLWATER Reactor in Los Pereyra, Tucumán, Argentina. J. Sol. Energy Eng. 2006, 129, 127-134. [CrossRef]

128. Bolte, M.; Klaeden, K.; Beqiraj, A.; Oelgemöller, M. Photochemistry Down under-Solar chemicals from and for the Tropics. Eur. Photochem. Assoc. Newslett. 2013, 83-84, 79-83.

129. Gallezot, P. Conversion of biomass to selected chemical products. Chem. Soc. Rev. 2012, 41, 1538-1558. [CrossRef]

130. Horikoshi, S.; Nishimura, T.; Tsutsumi, H.; Serpone, N. Microwave Discharge Electrodeless Lamps. Part VIII: Continuous On-Site Solar Energy Remediation of Contaminated Water. Chem. Eng. Technol. 2015, 39, 102-107. [CrossRef]

131. Lui, G.Y.; Roser, D.; Corkish, R.; Ashbolt, N.; Jagals, P.; Stuetz, R. Photovoltaic powered ultraviolet and visible light-emitting diodes for sustainable point-of-use disinfection of drinking waters. Sci. Total Environ. 2014, 493, 185-196. [CrossRef]

132. Vassilikogiannakis, G. Singlet Oxygen and Dyes: Synthesis with Visible Light is Where the Future Lies. ChemPhotoChem 2020, 4, 385-387. [CrossRef]

133. Montagnon, T.; Kalaitzakis, D.; Triantafyllakis, M.; Stratakis, M.; Vassilikogiannakis, G. Furans and singlet oxygen-why there is more to come from this powerful partnership. Chem. Commun. 2014, 50, 15480-15498. [CrossRef]

134. Dinda, M.; Maiti, S.; Samanta, S.; Ghosh, P.K. Illustrations of Efficient Solar Driven Organic Reactions. Curr. Org. Synth. 2016, 13, 372-384. [CrossRef] 
135. Li, P.; Terrett, J.A.; Zbieg, J.R. Visible-Light Photocatalysis as an Enabling Technology for Drug Discovery: A Paradigm Shift for Chemical Reactivity. ACS Med. Chem. Lett. 2020, 11, 2120-2130. [CrossRef]

136. McAtee, R.C.; McClain, E.J.; Stephenson, C.R. Illuminating Photoredox Catalysis. Trends Chem. 2019, 1, 111-125. [CrossRef]

137. Douglas, J.J.; Sevrin, M.J.; Stephenson, C.R.J. Visible Light Photocatalysis: Applications and New Disconnections in the Synthesis of Pharmaceutical Agents. Org. Process. Res. Dev. 2016, 20, 1134-1147. [CrossRef]

138. Nauth, A.M.; Lipp, A.; Lipp, B.; Opatz, T. Sunflow: Sunlight drives fast and green photochemical flow reactions in simple microcapillary reactors-application to photoredox and H-atom-transfer chemistry. Eur. J. Org. Chem. 2017, 2017, 2099-2103. [CrossRef]

139. Yaseen, M.A.; Mumtaz, S.; Hunter, R.L.; Wall, D.; Robertson, M.J.; Oelgemöller, M. Continuous-flow photochemical transformations of 1,4-naphthoquinones and phthalimides in a concentrating solar trough reactor. Aust. J. Chem. 2020, 73, 1149-1157. [CrossRef]

140. Yaseen, M.A.; Mumtaz, S.; Hunter, R.L.; Wall, D.; Robertson, M.J.; Oelgemöller, M. Corrigendum to: Continuous-flow photochemical transformations of 1,4-naphthoquinones and phthalimides in a concentrating solar trough reactor. Aust. J. Chem. 2020, 73, 1301. [CrossRef]

141. Papakonstantinou, I.; Portnoi, M.; Debije, M.G. The hidden potential of luminescent solar concentrators. Adv. Energy Mater. 2020, 11. [CrossRef]

142. Poliakoff, M.; George, M.W. Manufacturing chemicals with light: Any role in the circular economy? Phil. Trans. R. Soc. A 2020, 378, \#20190260. [CrossRef] [PubMed]

143. Bochet, C.G. On the Sustainability of Photochemical Reactions. Chim. Int. J. Chem. 2019, 73, 720-723. [CrossRef]

144. Michelin, C.; Hoffmann, N. Photocatalysis applied to organic synthesis-A green chemistry approach. Curr. Opin. Green Sustain. Chem. 2018, 10, 40-45. [CrossRef]

145. Oelgemöller, M.; Oelgemoeller, M. Green Photochemical Processes and Technologies for Research \& Development, Scale-up and Chemical Production. J. Chin. Chem. Soc. 2014, 61, 743-748. [CrossRef]

146. Ciana, C.-L.; Bochet, C.G. Clean and Easy Photochemistry. Chim. Int. J. Chem. 2007, 61, 650-654. [CrossRef]

147. Albini, A.; Fagnoni, M.; Mella, M. Environment-friendly organic synthesis. The photochemical approach. Pure Appl. Chem. 2000, 72, 1321-1326. [CrossRef]

148. Ciriminna, R.; Delisi, R.; Xu, Y.-J.; Pagliaro, M. Toward the waste-free synthesis of fine chemicals with visible light. Org. Process Res. Dev. 2016, 20, 403-408. [CrossRef]

149. Oelgemöller, M. The sunny side of chemistry at James Cook Uni. Chemistry in Australia, November $2014 ; 7$. 